\title{
Virus-Host Interactions of Enteroviruses and Parvovirus B19 in Myocarditis
}

\author{
Huyen Tran Ho Stefan Peischard Nathalie Strutz-Seebohm Guiscard Seebohm \\ Cellular Electrophysiology and Molecular Biology, Institute for Genetics of Heart Diseases (IfGH), \\ University Hospital Münster, Münster, Germany
}

\section{Key Words}

RNA Virus $\bullet$ Infection $•$ Apoptosis $\bullet$ Myocarditis $\bullet$ Protease

\begin{abstract}
Viral diseases are a major threat to modern society and the global health system. It is therefore of utter relevance to understand the way viruses affect the host as a basis to find new treatment solutions. The understanding of viral myocarditis (VMC) is incomplete and effective treatment options are lacking. This review will discuss the mechanism, effects, and treatment options of the most frequent myocarditis-causing viruses namely enteroviruses such as Coxsackievirus B3 (CVB3) and Parvovirus B19 (PVB19) on the human heart. Thereby, we focus on: 1. Viral entry: CVB3 use Coxsackievirus-Adenovirus-Receptor (CAR) and Decay Accelerating Factor (DAF) to enter cardiac myocytes while PVB19 use the receptor globoside (Gb4) to enter cardiac endothelial cells. 2. Immune system responses: The innate immune system mediated by activated cardiac toll-like receptors (TLRs) worsen inflammation in CVB3-infected mouse hearts. Different types of cells of the adaptive immune system are recruited to the site of inflammation that have either protective or adverse effects during VMC. 3. Autophagy: CVB3 evades autophagosomal degradation and misuses the autophasomal pathway for viral replication and release. 4. Viral replication sites: CVB3 promotes the formation of double membrane vesicles (DMVs), which it uses as replication sites. PVB19 uses the host cell nucleus as the replication site and uses the host cell DNA replication system. 5. Cell cycle manipulation: CVB3 attenuates the cell cycle at the G1/S phase, which promotes viral transcription and replication. PVB19 exerts cell cycle arrest in the S phase using its viral endonuclease activity. 6. Regulation of apoptosis: Enteroviruses prevent apoptosis during early stages of infection and promote cell death during later stages by using the viral proteases $2 \mathrm{~A}$ and $3 \mathrm{C}$, and viroporin 2B. PVB19 promotes apoptosis using the non-structural proteins NS1 and the 11 kDa protein. 7. Energy metabolism: Dysregulation of respiratory chain complex expression, activity and ROS production may be altered in CVB3- and PVB19-mediated myocarditis. 8. Ion channel modulation: CVB3-expression was indicated to alter calcium and potassium currents in Xenopus laevis oocytes and rodent cardiomyocytes. The phospholipase 2-like activity of
\end{abstract}

Prof. Dr. Nathalie Strutz-Seebohm and Prof. Dr. Guiscard Seebohm
Department of Cardiovascular Medicine, Institute for Genetics of Heart Diseases (IfGH), University Hospital Muenster, Robert-Koch Straße 45, D-48149 Muenster (Germany); Tel. +49 (0)251/83-58255, Fax +49 (0)251/83-58257,

E-Mail nathalie.strutz-seebohm@ukmuenster.de; guiscard.seebohm@ukmuenster.de 
PVB19 may alter several calcium, potassium and sodium channels. By understanding the general pathophysiological mechanisms of well-studied myocarditis-linked viruses, we might be provided with a guideline to handle other less-studied human viruses.

\section{Relevance of CVB3 and PVB19 in Viral Myocarditis}

Myocarditis is the process of inflammation in the myocardium. One cause for myocarditis are viruses, that infect the host's heart. The severity of viral myocarditis (VMC) varies between a light illness with flu-like symptoms and gastrointestinal illness to severe dilated cardiomyopathy (DCM) and sudden cardiac death [1]. In western countries the most prominent cause for myocarditis is chronic viral infection and evidence is emerging that also the newly emerged SARS-CoV-2 can cause myocarditis [2, 3]. Dadashi et al. recently conducted a thorough review and meta-analysis of the prevalence of most common viruses in viral myocarditis including 75 studies from 1973 to 2018 performed in highly industrialized nations. In conclusion, the viruses with the highest prevalence rates were parvovirus B19 (PVB19) with 25.0\% and non-polio enteroviruses with 18\% [4]. However, the relevance of PVB19 is questionable, as the prevalence of PVB19 in healthy hearts is similar to hearts with diagnosed myocarditis (MC) or DCM [5]. Anyhow, it is proposed that a high viral load of over 500 ge (genome equivalents) and active replication of PVB19 could result in myocarditis in about $64.7 \%$ of myocarditis patients [6]. Additional co-infection with another cardiotropic virus in parallel to a PVB19 infection might even elevate the chance of myocarditis development [7, 8]. Kuhl et al. were able to support this hypothesis: They observed a clear difference between latent and transcriptionally active PVB19 in human endomyocardial biopsies. Thus, the shift from latent PVB19 to transcriptionally active, potentially caused by transactivating viruses (e.g. human herpes virus 6) and/or immune suppression, can result in the emergence of myocardial dysfunction [9].

Since viruses are the main cause for myocarditis, it is important to investigate and find treatments against the viruses that most commonly cause myocarditis, namely PVB19 and enteroviruses. By understanding these viruses, parallels to other, even less understood viruses, might be drawn. Hence, this review focuses on the effects of enteroviruses such as Coxsackievirus B3 (CVB3) and PVB19 on the human heart in order to understand underlying mechanisms of the pathogenesis of viral myocarditis and to discuss novel treatment options. Since there is a current lack of efficient treatment and cure against myocarditis viruses [10, $11]$, it is even more important to understand the common modi operandi of the respective viruses.

Viruses use the host cell to their advantage to reproduce and distribute viral particles by reprogramming intracellular mechanisms of the host cell. These mechanisms include immune responses, autophagy, formation of viral replication sites, cell cycle alterations, apoptosis, energy metabolism, and electrophysiological alterations that will be addressed in the next sections.

\section{Viral genomes of Enteroviruses (Coxsackievirus B3) and Parvovirus B19}

Viral genomes are customarily small and therefore code only for a few structural proteins forming the viral capsid and non-structural proteins which control the host cellvirus interactions. These interactions serve to promote viral replication and virus assembly and they vary depending on the virus type $[12,13]$. PVB19 is an ssDNA virus while CVB3 is an ssRNA virus. Both are non-enveloped viruses and are considered comparatively small with genome sizes of $7.4 \mathrm{~kb}$ (CVB3) and $5.6 \mathrm{~kb}$ (PVB19) respectively [14, 15]. 
CVB3

The picornaviral genome is coding for the structural proteins VP1-VP4 and for the nonstructural proteins 2A-3D (Fig. 1) [16, 17]. As previously mentioned, the structural proteins form the capsid. Differential proteolysis of the polyprotein gives rise to non-structural proteins, such as viral proteases $2 \mathrm{~A}, 3 \mathrm{C}$, and $3 \mathrm{CD}$, a viral polymerase (3D), a viroporin (2B), and proteins for viral encapsulation (2C), membrane permeabilization (3C), and viral replication (2BC) [17]. The genomic ssRNA is not capped at the $5^{\prime}$ end but the viral 3B protein, also called virion protein genome linked (VPg), is recruited to the $5^{\prime}$ end, which serves as a primer for viral replication [18]. Moreover, the CVB3 genome inherits an internal ribosome entry site (IRES) at the 5' end that mediates translation of the viral RNA [19].

\section{PVB19}

The PVB19 genome is flanked by two identical inverted terminal repeats (ITRs), that each form a hairpin. PVB19 expresses the three non-structural proteins NS1, a $11 \mathrm{kDa}$, a $7.5 \mathrm{kDa}$ protein, and the structural proteins VP1 and VP2, which form the capsid (Fig. 2) [20-22]. VP1 makes up 4\% and VP2 96\% of the viral capsid [21]. The viral capsid proteins are transported inside the host cell nucleus, because VP2 harbors a nuclear localization signal. The same applies to the NS1 protein that inherits two nuclear localization signals [23]. The function of the $7.5 \mathrm{kDa}$ protein is still unknown. The $11 \mathrm{kDa}$ protein localizes in the cytoplasm. It is 10 times more abundant than the full-size NS1 and induces apoptosis in erythroid progenitor cells. Inhibition of its mRNA via antisense oligos shows significant decrease in apoptosis in PVB19-infected erythroid progenitor cells [24]. The NS1 protein is found to have multiple functions: DNA binding and cleavage, helicase activity, DNA damage response, cell cycle arrest, transactivation and apoptosis [22, 25].

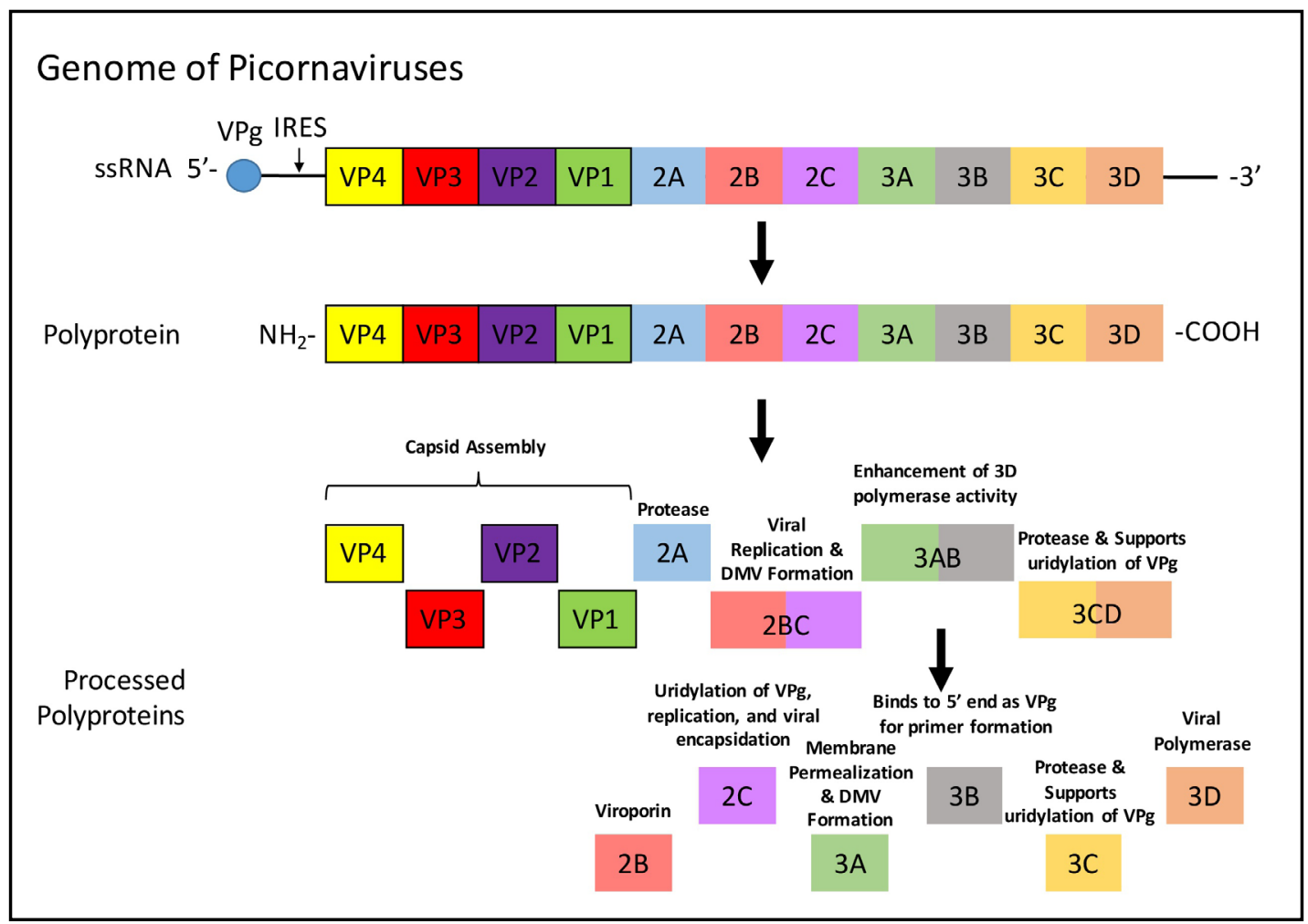

Fig.1. Genome of Picornaviruses and the known functions of the translated proteins. 


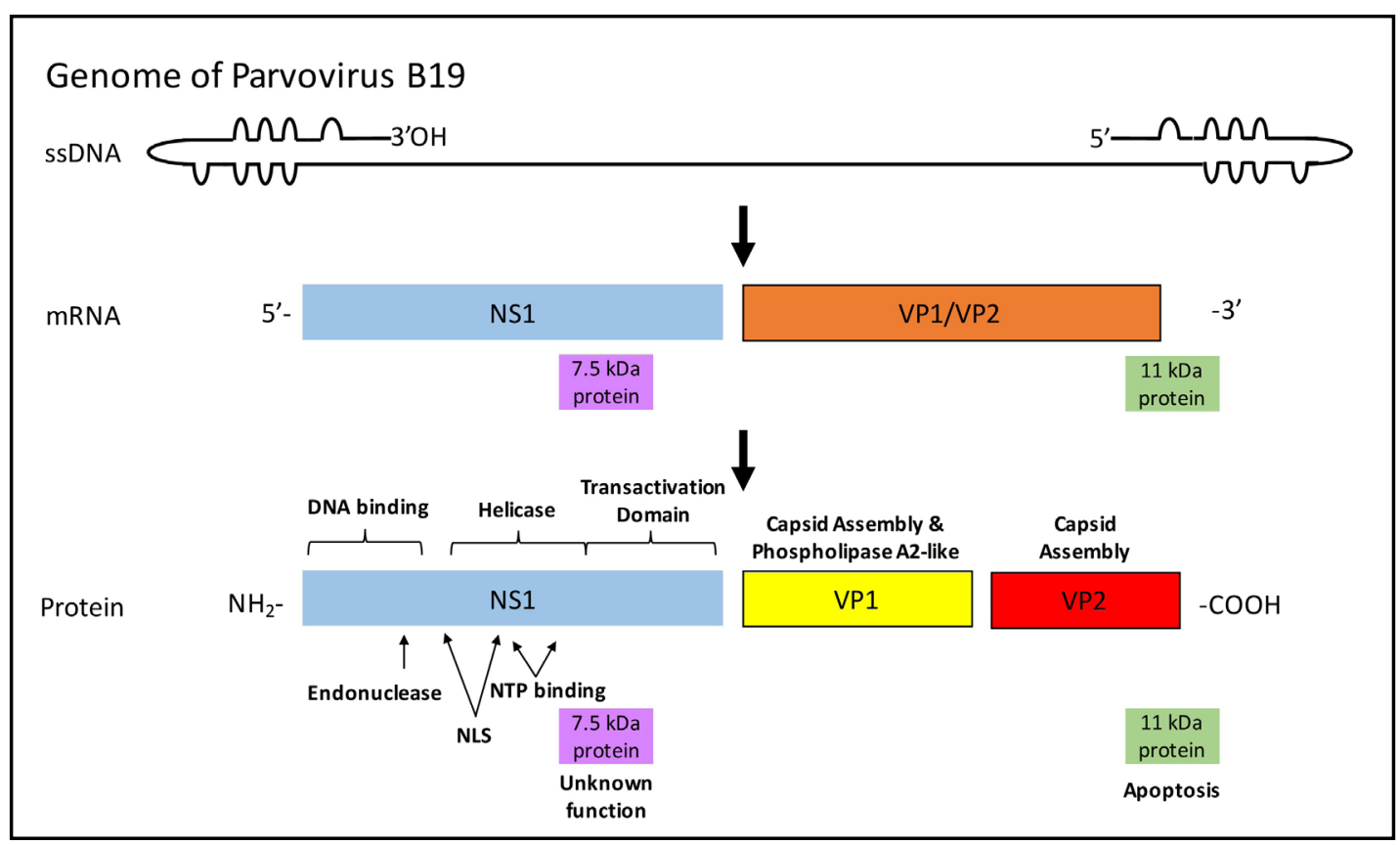

Fig. 2. Genome of Parvovirus B19 and the known functions of the translated proteins.

\section{Disease Progression of Viral Myocarditis: The Fight between Virus and the Immune System}

Viral Entry

The mechanisms in which a viral infection results in myocarditis are diverse and depend on the virus. Enteroviruses and adenoviruses directly infect cardiac myocytes, whose lysis and resulting immune system activation leads to myocarditis. In contrast, patients with fulminant PVB19 myocarditis suffer cardiac endothelial cell infection, predominantly in venules, and to a lesser degree in small arteries, and arterioles [26].

The progression of myocarditis can be divided into three main phases $[5,10,27]$ : Phase 1: Viral entry and activation of the innate immune system, phase 2: Activation of the adaptive immune response, and phase 3: Recovery or disease progression.

CVB3. Enteroviruses enter the body via the respiratory or gastrointestinal tract. The heart is infected secondarily.

Phase 1 starts with the entry of the virus into the target cells, which takes minutes up to hours. Enteroviruses and adenoviruses enter cardiomyocytes by binding to the cell-specific surface proteins called Coxsackievirus-Adenovirus-Receptor (CAR) and Decay Accelerating Factor (DAF) (see Fig. 3A) [28, 29]. Inhibition of enterovirus binding to CAR and DAF by soluble recombinant CAR or DAF is shown to alleviate cardiac dysfunction and reduce viral load in mice with enteroviral myocarditis [30,31].

PVB19. PVB19 primarily uses the receptor globoside (Gb4), also called P antigen receptor protein, to facilitate its entry into the target cell (see Fig. 3A). Humans and knockout cells deficient for Gb4 were shown to be resistant to PVB19 infections [22, 32, 33]. However, recently it has been demonstrated that Gb4 is not necessary for the initial entry of PVB19 but rather it is relevant in a post-entry step of infection [33]. Gb4 is activated and expressed more increasingly in vascular endothelial cells by tumor necrosis factor- $\alpha$ (TNF- $\alpha$ ) stimulation, thus possibly being enhanced during inflammation [34]. Potentially, PVB19 infection progresses in inflamed endothelial tissue, which should be further studied. There are also other co- 
receptors like Ku80, and integrin $\alpha 5 \beta$ that could facilitate and mediate PVB19 entry into the cell $[22,35,36]$. Additionally, entry of PVB19 may be enhanced via antibody-dependent mechanisms, but this hypothesis is not sufficiently investigated, yet [37, 38].

Inside the host cell, the viral genome is transported into the nucleus through nuclear pores and its genetic information is replicated. Subsequent translation into functional proteins is required for the generation of new viral particles and is performed by host cell ribosomes. These proteins include structural proteins like capsid proteins, and non-structural proteins, that manipulate the host cell function to the advantage of the virus. During the time of viral replication, the viral proteases initiate cell apoptosis and necrosis [26, 39, 40].

\section{Activation of Innate Immune System}

CVB3. Within 1 to 7 days post infection cardiac toll-like receptors (TLRs) recognize general infection patterns and initiate the release of pro-inflammatory cytokines like interleukin-1 $\beta$ (IL-1 $\beta$ ), IL-6, IL-18, TNF- $\alpha$, and type I and type II interferons (IFNs) that are secreted by myocytes, endothelial cells, fibroblasts, and dendritic cells (see Fig. 3B) [41, 42]. TLR 3, TLR 7, TLR 8, and TLR 9 play a particularly large role in viral myocarditis, as TLR 3 recognizes viral dsRNA, TLR 7/8 ssRNA, and TLR 9 bacterial and viral CpG DNA motifs [41]. TLR 3, TLR 4 and TLR 9 activation after recognizing pathogen-associatedmolecular-patterns (PAMPs) during VMC was shown to worsen the severity of inflammation in CVB3-infected mouse hearts. In line, specific inhibition of TLR 3 and TLR 4 function by MiR-146a, an anti-TLR9 oligodeoxynucleotide, or Lupeol alleviated the CVB3-triggered cardiac inflammation, making TLR-specific therapy a possible option for VMC patients [4345]. Secreted cytokines appear to be either beneficial or detrimental during viral myocarditis, depending on the cytokine, timing of secretion or administration, and secreted amount. Blocking IL-1ß signaling in CVB3-mediated myocarditis reduces inflammation, fibrosis, and cardiac remodeling, therewith preventing progression towards chronic myocarditis in

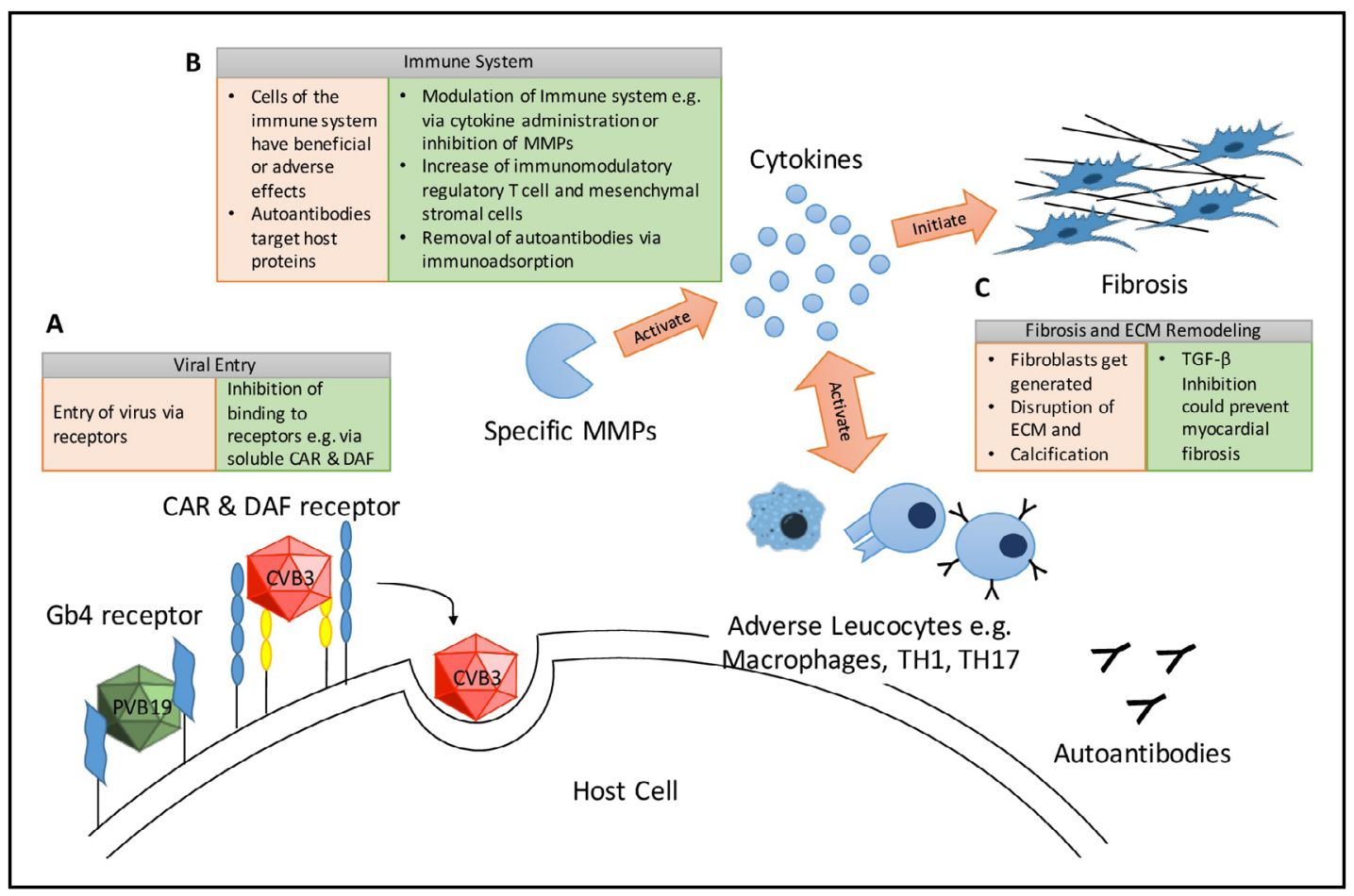

Fig. 3. Most relevant effects of PVB19 and CVB3 on viral myocarditis outside of the host cell. Viral effects (red boxes) and respective possible treatment options (green boxes) are described. PVB19, Parvovirus B19; CVB3, Coxsackievirus B3, CAR, Coxsackievirus-Adenovirus-Receptor; DAF, Decay Accelerating Factor; MMP, Matrix-Metallo-Proteinase; ECM, extracellular matrix; TGF- $\beta$, Transforming Growth Factor- $\beta$. 
mice [46]. In Balb/c mice and human myocardial fibroblasts infected with CVB3, exogenous administration of IFN- $\beta$ had alleviating effects $[47,48]$. In clinical studies, administration of IFN- $\beta$ to patients with myocardial enteroviral or adenoviral persistence and left ventricular (LV) dysfunction is shown to be compliant. Additionally, complete viral clearance in all patients, accompanied with improved $\operatorname{LV}$ function and survival rate was observed $[49,50]$.

Absence of IFN- $\gamma$ does not have any significant effects on CVB3-infected mice, while overexpression of IFN- $\gamma$ had alleviating effects on murine CVB3-induced myocarditis $[51,52]$. IFN signaling leads to the Janus Kinase (JAK)-signal transducer and activator of transcription (STAT) pathway activation. Inhibiting this pathway via Suppressor of Cytokine Signaling, SOCS-1 and SOCS-3, increases cardiac damage and elevates viral replication [53, 54].

Another important pro-inflammatory cytokine is TNF- $\alpha$. Mice that are administered or express TNF- $\alpha$ show enhanced cardiac damage, but also enhanced viral clearance after CVB3 or encephalomyocarditis virus (EMCV) infection [55, 56]. Additionally, complete systemic depletion of TNF- $\alpha$ is shown to be detrimental in murine EMCV myocarditis [57]. Hence, the dose and the timing of TNF- $\alpha$ administration or inhibition is critical for myocarditis attenuation.

Through these cytokines, cells of the innate immune system including natural killer cells (NK cells), natural killer T cells (NKT cells), macrophages, monocytes, and dendritic cells are recruited to the infected area [42]. The presence of NK and NKT cells is assumed to be beneficial during the early phase of viral myocarditis $[58,59]$. Other cells of the innate immune system appear to rather have a negative effect on infected tissue. This notion is supported as depletion of the innate immune system cells via Mac-1 antibodies reduces viral load and inflammation in EMCV-caused myocarditis in mice. Mac- 1 antibodies inhibit macrophages, monocytes, and NK cells, which underlines the observed effects [60]. Membrane-bound dipeptidase 2 (DPEP2) suppresses macrophage inflammation by inhibiting NF- $\kappa B$ signaling, thereby having protective effects in CVB3-induced myocarditis [61].

Extracellular matrix (ECM) molecules are also upregulated by cytokines. ECM components are key regulators in cardiac remodeling and of inflammatory processes as they prime the site of infection accessible for leucocytes [62]. Matrix metalloproteinases (MMPs) are enzymes that regulate components of the ECM in order to remodel the tissue in physiological and pathophysiological processes including inflammation and tissue injury (see Fig. 3C). They can cleave cytokines, chemokines, and growth factors, therefore modulating them appropriately in response to the predominant tissue condition $[63,64]$. MMP-2, -3, -8, -9, and -13 as well as some of their inhibitors called tissue inhibitors of metalloproteinases (TIMPs) namely TIMP-1 and -2 are found to be upregulated in CVB3infected mice [65]. The enhanced production of e.g. MMP-9 in the myocardium is discussed to be activated by TLR activation in myofibroblasts. This TLR activation leads to the secretion of chemokines and to the activation of heart-infiltrating leukocytes directly worsening cardiac inflammation. Furthermore, activated leukocytes produce MMP-9, which is a strong trigger for the promotion of fibrosis [27]. Lowering the MMP level by overexpression of inhibitors like TIMP-1, plasminogen activator inhibitor-1 (PAI-1), or carvedilol decreases cardiac inflammation, cardiac necrosis and fibrosis, and reduces cardiac dilation and dysfunction in CVB3-infected mice underscoring the role of MMPs in the pathogenesis of viral myocarditis $[65,66]$. However, MMPs have to be targeted selectively. Lack of MMP-8 has no effect on viral load, but lack of MMP-9 or MMP-3 worsens the condition of CVB3-infected mice including higher myocardial damage, dysfunction, viral load, and immune cell infiltration $[67,68]$.

PVB19. So far, there are no studies that investigate the role of TLRs in PVB19-mediated myocarditis. In PVB19-infected cultured endothelial cells and patients with cardiac persistence of PVB19 administration of IFN- $\beta$ led to normalization of endothelial function and decrease in viral load $[69,70]$. The in-vitro experiments indicate that these ameliorating effects are due to replication suppression of transcriptionally active PVB19 intermediates [69]. 
The Adaptive Immune System

CVB3. In phase 2 the adaptive immune system responds to the viral infection (see Fig. 3B). This phase is characterized by high viral replication and inflammatory processes. Therefore, the most severe tissue damages occur in this phase $[1,71,72]$. Phase 2 includes elevated release of cytokines especially TNF, IL-1a, IL-1b, IL-2, IFN- $\gamma$ and the recruitment of virusspecific T- and B-lymphocytes, which are accompanied by cellular and humoral antibodies to detect and destroy the infection [10]. Heart-reactive autoantibodies are produced in most myocarditis patients that detect and immobilize own cardiac proteins. Autoantibodies targeting myosin, $\beta 1$-adrenergic receptors, cardiac troponin I, cardiac mitochondria, and others are produced [73]. Removal of antibodies via immunoadsorption in DCM patients in pilot studies improved cardiac function and reduced cardiac inflammation $[74,75]$. In contrast, in chronic DCM patients, troponin I autoantibodies had a cardio-protective effect [76]. The role of the immune system on CVB3 VMC is summarized in a facilitated review article by Corsten et al. [42]. They are able to conclude that overall NK cells, M2 macrophages, T-helper 2 cells, regulatory T cells, and B cells are cardioprotective while M1 macrophages, T-helper 1 cells, cytotoxic T cells and $\gamma \delta+\mathrm{T}$ cells have adverse effects during VMC. These autoimmune responses as well as the more protuberant effects of the virus itself, like viral protease activity, lead to damage in the ECM proteins, contractile apparatus, and interstitial cells [10]. In addition, T-helper 17 cells are described to contribute to CVB3 replication by producing autoantibodies e.g. against cardiac ANT promoting heart failure in myocarditis [77-79]. Integrin CD11b appears to contribute to T-helper 17 cell induction [80]. Reducing T-helper 17 cells in VMC could be a promising target for therapy. In contrast, regulatory $\mathrm{T}$ cells and mesenchymal stromal cells, that have immunomodulatory effects, are beneficial in CVB3-mediated myocarditis. They reduce the recruitment of monocytes to the heart. Transferring regulatory $T$ cells or mesenchymal stromal cells, or using agonists that promote production of these cells could be a promising therapy concept as well [81-83].

PVB19. PVB19-mediated myocarditis exerts endothelial damage similar to CVB3mediated myocarditis. PVB19 infection also leads to activation of the cytokines TNF- $\alpha$ and IL-6. Further, PVB19 infection is associated with the upregulation of adhesion molecules, which causes accumulation of T-lymphocytes in the myocardium, and induction of apoptosis in endothelial cells, which could ultimately lead to ischemia and cardiomyopathy [26].

\section{Recovery or Disease Progression}

CVB3 and PVB19. In phase 3, the disease can progress either towards viral clearance and recovery or towards irreversible chronic DMC. Around $60 \%$ to $70 \%$ of myocarditis patients recover from the infection with healed injury due to an intact immune system [84]. In severe injuries, caused by apoptosis or necrosis of the myocardium, the contractile myocardium tissue cannot heal due to lack of cardiac precursor cells that could generate more cardiomyocytes. In these cases, pathologic remodeling and fibrosis occurs causing DCM or heart failure (see Fig. 3C). Transforming Growth Factor- $\beta$ (TGF- $\beta$ ) signaling is indicated in ischemic heart diseases and myocarditis to be the key in the transition from acute inflammation to fibrosis [85]. Concordantly, inhibition of TGF- $\beta$ in mice with induced experimental autoimmune myocarditis prevents myocardial fibrosis [86]. TGF- $\beta$ signaling is demonstrated to affect heart-infiltrating CD133+ hematopoietic cells in mice with induced autoimmune myocarditis which then generate myofibroblasts leading to fibrosis [86]. The myofibroblasts excessively produce collagen and tip the MMP and TIMP balance, thus disrupting the ECM. This leads to cardiac fibrosis and ultimately DCM [87]. In very severe cases, calcification of the myocardium can occur leading to a poor prognosis for the patient [88].

Moreover, even after viral clearance, it is possible that myocardial inflammation still persists. This may be due to cross-reactive antibodies produced against the virus but also recognize antigens of the hosts. This mechanism is called molecular mimicry [89]. 
Immunomodulatory Treatment against Viral Myocarditis

It becomes evident that the immune reaction plays a crucial role in fighting against the viral infection and at the same time causing pathologic cardiac phenotypes. Immunomodulation in combination with antiviral drugs as treatment option in VMC could be promising, but studies are still lacking [90]. So far, infectious myocarditis has to be ruled out to start immunosuppression, while in some non-infectious myocarditis scenarios immunosuppressive treatment is mandatory [2, 91]. IFN- $\beta$ treatment against CVB3 myocarditis is considered promising as mentioned previously. Recently, it has been shown that the use of the mineralocorticoid receptor antagonist eplerenone during the first acute phase of infection is beneficial in murine CVB3-mediated myocarditis by reducing infiltration of monocytes and macrophages, oxidative stress, apoptosis, and fibrosis [92]. Cannabidiol also has immunomodulatory effects and is shown to reduce $\mathrm{T}$ cell-mediated inflammation and had alleviated effects in mice with experimental autoimmune myocarditis [93]. A recent phase 3 study using intravenous immunoglobulin therapy (IVIg), shown effective in several autoimmune and autoinflammatory diseases, showed no noteworthy effect in PVB19mediated myocarditis $[94,95]$. Hence, immunomodulation as therapy in viral myocarditis has to be further evaluated.

\section{Autophagy in CVB3-Mediated Myocarditis}

Autophagosome formation is an innate cell response for pathogen removal or for protein recycling and degradation. However, some viruses can evade autophagosomal degradation and misuse autophagy to their advantage: CVB3 seems to have the ability to stimulate autophagosome formation as shown in HeLa cells and in murine cardiomyocyte cell line HL-1. The CVB3 3C protease inhibits lysosome-autophagosome fusion by cleaving synaptosomal-associated protein 29 , which is part of the SNARE complex connecting lysosomes and autophagosomes [96, 97]. Additionally, CVB3 uses autophagic components for the formation of extracellular microvesicles (EMVs) which contain CVB3 virions. This indicates that CVB3 uses EMVs for viral release (see Fig. 4B) [97, 98]. In addition, formation of these autophagosomes appears to be relevant for CVB3 replication, by using them as replication organelles (ROs). Consistently, in electron microscopy, the ROs of CVB3 resemble autophagosomal structures [99-101]. These RO structures might promote the formation of double membrane vesicles (DMVs). Thus, inhibition of autophagosome formation e.g. by 3-methyl-adenine or small interfering RNAs that target autophagosome formationpromoting genes is shown to reduce viral replication of CVB3, poliovirus, and rhinoviruses 2 and 14 in-vitro $[99,102]$. Inhibition of autophagosome formation seems to be an interesting therapy approach that needs further investigation in more relevant disease models for myocarditis.

\section{Replication Sites of Enteroviruses and Parvovirus B19}

\section{CVB3}

Some positive stranded RNA viruses, that include enteroviruses, alter the host cell membrane in order to generate DMVs as replication sites [103, 104]. In these DMVs, components of a replicase complex are anchored. They create a protected environment against the detection of dsRNA intermediates by the host cell innate immunity. As a consequence, virions can mature in DMVs finally allowing for non-lytic release of the virus [105]. The organelles that are misused to promote DMV formation are called replication organelles (ROs). Pathways of autophagy, lipid metabolism and secretion are found to contribute to RO biogenesis [106]. DMVs of enteroviruses are not connected to other cellular membranes. Those DMVs exist in open vase-like structures, and form multilamellar vesicles in later infection stages [107]. Enteroviral ROs originate from the endoplasmic reticulum (ER) and 


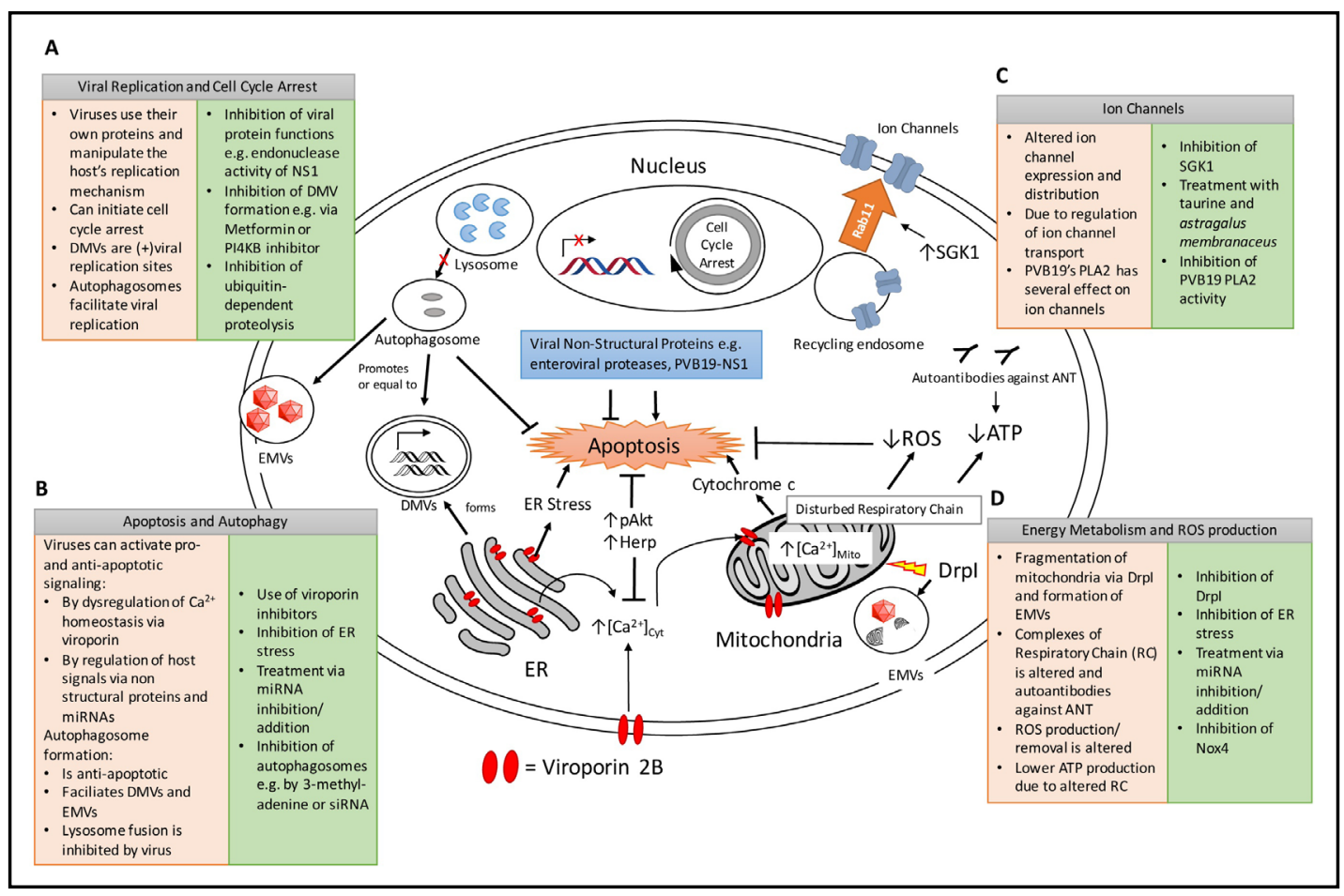

Fig. 4. Most important effects of PVB19 and CVB3 on viral myocarditis inside the host cell regulating several cellular processes. Viral effects (red boxes) and respective possible treatment options (green boxes) are described. DMV, double membrane vesicle; NS1, nonstructural protein 1; PI4KB, Phosphatidylinositol 4-kinase beta; EMV, extracellular microvesicle; ER, endoplasmic reticulum; PLA2, Phospholipase 2; PVB19, Parvovirus B19; SGK1, serum and glucocorticoid-regulated kinase 1; Drp1, Dynamin-related protein 1; ANT, Adenine Nucleotide Translocator; ROS, reactive oxygen species; ATP, adenosine triphosphate.

Golgi membranes [108]. In polioviruses, the 3A and 2BC non-structural proteins induce DMV formation from ROs [109]. CVB3 can either abuse components of the autophagy pathway for the formation of DMVs or it can create replication sites in an autophagy-independent manner [110]. Enteroviruses can use their viral proteins to recruit several host proteins to promote RO biogenesis. Inhibiting RO formation via small molecule compounds is suggested to be a promising treatment target, as these agents are able to reduce viral replication [106]. For example, using an inhibitor against phosphatidylinositol 4-kinase beta (PI4KB), which is a RO inducer, leads to a decrease in viral RNA replication. This decrease can be rescued by a mutation in the 3A protein of CVB3, which leads to R0-independent virus replication in the Golgi [111]. Activation of the AMP-activated protein kinase (AMPK) via Metformin reduces lipid accumulation and therewith disturbs RO formation in CVB3-infected HeLa cells [112]. Therefore, inhibiting the formation of ROs and DMVs appears to be an attractive treatment option. Upon virion assembly, the virion is released either via cell lysis or via extracellular microvesicles (EMVs). The EMVs contain autophagosomal markers. This could indicate that EMVs either originate from autophagasomes or that they use the autophagosomal pathway for virion release [98].

\section{PVB19}

PVB19 uses the host cell nucleus as the site for viral replication, transcription, and encapsidation. As previously mentioned (see section 2), PVB19 proteins have nuclear localization signals that guide the proteins inside the host nucleus. They depend on the host cell DNA replication system as PVB19 does not encode a polymerase [22]. Thus, PVB19 attenuates the host cell cycle to their advantage where certain host cell replication factors are present and active as discussed in the next section. 


\section{Cell Cycle Arrest Promotes Viral Replication}

\section{CVB3}

Viruses can induce cell cycle arrest to promote viral replication (see Fig. 4A). Coxsackievirus infection is shown to inhibit host cell proliferation. In HeLa and neuronal progenitor cells CVB3 causes cell cycle arrest at G1/S phase by increasing the ubiquitindependent proteolysis of cyclin D1 and p53 [113, 114]. Inhibition of ubiquitin-dependent proteolysis via MG-132, lactacystin, and pyrrolidine dithiocarbamate reduces CVB3 replication in CVB3-induced myocarditis in mice $[115,116]$. Moreover, it is shown that the CVB3 VP1 protein can induce cell cycle arrest at the G1 phase in cardiac myocytes by inducing the heat shock protein 70 which in turn downregulates cycline $E$ and upregulates $\mathrm{p} 27^{\mathrm{Kip} 1}$ [117]. Data indicate that in the G1 or G1/S phase coxsackieviruses are able to produce more viral polyproteins and viral progeny than in quiescent cells at G0 phase [118]. Apparently, the cell cycle status plays a crucial role in enteroviral replication, persistence, and reactivation. However, in adult cardiomyocytes cell cycle arrest may be less relevant as in other cardiac cells, due to an almost complete stop of cell division.

\section{PVB19}

The NS1 protein (endonuclease activity) of PVB19 participates in viral DNA replication as it binds to the viral DNA to initiate DNA replication [119]. It is shown that the inhibition of the endonuclease activity of NS1 by certain flavonoid compounds inhibits PVB19 DNA replication, thus making NS1 a promising treatment target [120]. DNA replication of parvoviruses mainly occurs in the S-phase of the host cell replication cycle, in which cellular S-phase replication factors are provided, which the virus can use for its own replication. Knocking down $S$ phase factors such as minichromosome maintenance complex protein 2 (MCM2) or MCM5 shows significant decrease in PVB19 DNA replication in erythroid precursor cells (EPCs). Concordantly, NS1 of PVB19 is able to arrest cell cycle in late S phase in EPCs [121].

In conclusion, inhibiting viral protein activity that participates in viral replication can be promising treatment targets. Manipulating cell cycle regulation in favor for the host cell could also be an approach but has to be thoroughly evaluated due to possible teratogenic and carcinogenic effects.

\section{Viral Regulation of Apoptosis}

\section{Enteroviruses (CVB3)}

Enteroviruses are typically known to be lytic viruses. This means that for viral release, they often destruct host cell membranes, which leads to cell death. However, evidence is emerging that enteroviruses can also release virions in a non-lytic way in vesicles also discussed in section 5 [122]. Lytic viruses are known to be able to regulate cell apoptosis to their advantage, i.e. by inhibiting apoptosis in order to efficiently replicate inside the host cells in early stage of infection. In later infection phases enteroviruses induce apoptosis to facilitate the release of the virus via cell lysis $[123,124]$.

Enteroviruses can use their proteases $2 \mathrm{~A}$ and $3 \mathrm{C}$ to suppress apoptosis by cleaving host cell proteins that are important for apoptosis induction, like retinoic acid-induced gene 1 (RIG-1) [125-127], melanoma differentiation-related gene 5 (MDA-5) [128], TIR domaincontaining adaptor-inducing $\beta$-interferon (TRIF) [129], and IFN- $\beta$ promotor stimulator 1 (IPS-1, also called MAVS or visa) $[129,130]$. Enteroviruses can also inhibit apoptosis by regulating the phosphoinositide 3-kinase / protein kinase B (PI3K / Akt) pathway. They enhance Akt phosphorylation, which decreases caspase-3- and PARP-cleavage shown in CVB3-infected cells [131]. Furthermore, inhibition of c-Jun $\mathrm{NH}_{2}$-terminal kinase (JNK)mediated cell death was shown in poliovirus- and enterovirus 71 (EV71)-infected cells [132, 133] (see Fig. 4B). Other possible ways of inhibiting apoptosis by enteroviruses include 
the upregulation of the endoplasmic reticulum transmembrane protein homocysteineinduced ER protein (Herp). This Herp inhibition reduces cytoplasmic $\mathrm{Ca}^{2+}$ by inhibiting the degradation of the $\mathrm{Ca}^{2+}$ channels Inositol 1,4,5-triphosphate receptor $\left(\mathrm{IP}_{3} \mathrm{R}\right)$ and Ryanodine receptor (RyR), which was shown in poliovirus infection [134]. Also, polioviruses can disturb the transport of the TNF receptor to the cell membrane which inhibits TNF-mediated apoptosis [135]. In CVB3-infected HeLa cells CVB3 increases autophagosome formation by activating calpain which also works anti-apoptotic [136, 137].

Viral proteases can not only suppress aspects of apoptosis but also induce other sets of apoptosis regulators: The 3C protease of EV71 can activate caspase-8 and caspase-9, thus indirectly activating caspase-3 [138]. Furthermore, 2A and 3C can induce cell death by activating caspases that in turn cleave the DNA repair enzyme PARP [139]. Other host cell apoptosis factors that are affected by enteroviral proteases $2 \mathrm{~A}$ or $3 \mathrm{C}$ are the telomerebinding protein PinX1 [140], heterologous ribonucleic acid protein A1 (hnRNP A1) [141], eukaryotic translation initiation factor 4G (eIF4G) [142], death-associated protein (DAP5) [143], and BH3-interacting domain death agonist (Bid) [142].

The 2B proteins in enteroviruses that are expressed by poliovirus, EV71 and CVB3 are viroporins that have pro- and anti-apoptotic effects, depending on the infection phase. Viroporins are proteins which act like ion channels that can semi-selectively conduct ions $[144,145]$. These enteroviruses use their viroporins to alter $\mathrm{Ca}^{2+}$ homeostasis and thus apoptosis. The viroporins are inserted into the plasma membrane, mitochondrial membrane, golgi apparatus, ER, and in the sarcoplasmic reticulum (SR). The viroporin insertion leads to a decrease of $\mathrm{Ca}^{2+}$ in the targeted organelles $[146,147]$. To compensate the decrease of $\mathrm{Ca}^{2+}$ in the organelles, the cell utilizes capacititative calcium entry (also called store-operated calcium entry (SOCE)), as a result of which the calcium ion channels in the plasma membrane open. This leads to an increase in cytoplasmic $\mathrm{Ca}^{2+}[148,149]$.

Pro-survival effects occur at the onset of infection and pro-apoptotic effects at later stages, due to the gradual increase of $\mathrm{Ca}^{2+}$ flux from the ER to the mitochondria and into the cytoplasm [150]: When the cytosolic $\mathrm{Ca}^{2+}$ level is only moderately increased, $\mathrm{Ca}^{2+}-$ sensitive transcription factors are activated which support virus replication and activate or accelerate $\mathrm{Ca}^{2+}$-dependent enzymatic processes. Uptake of $\mathrm{Ca}^{2+}$ by mitochondria can occur via mitochondrial $\mathrm{Ca}^{2+}$ uniporter (MCU), the mitochondrial NCX transporter (NCLX), and possibly through the aforementioned viroporins [151]. Increase of mitochondrial calcium concentration leads to the increase of ATP production usually to counteract a higher energy demand [152]. In addition, the CVB3 viroporin suppresses the cell death stimuli actinomycin D and cycloheximide that would usually activate caspase-3, but a clear connection between $\mathrm{Ca}^{2+}$-level manipulation induced by the viroporin and the inhibition of cell death stimuli has still to be established [147]. On the other hand, high concentrations of $\mathrm{Ca}^{2+}$ in mitochondria lead to initiation of the intrinsic apoptotic pathway by releasing cytochrome $c$ and activating caspase- 9 which in turn activates caspase- 3 and $-7[150,153$, 154]. Moreover, CVB3-induced myocarditis in mice exerts ER stress that promotes apoptosis and other cell death mechanisms. Inhibition of ER stress has an ameliorating effect on disease progression [155]. This can possibly be explained by viroporin expression, which disturbs

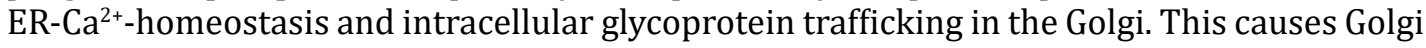
stress and remodeling of the ER membrane [156]. By self-localizing into mitochondria, the 2B protein of EV71 is shown to directly recruit Bcl-2-associated X protein (Bax). Bax in turn alters the permeability of the mitochondrial membrane leading to increased cytochrome $c$ release and caspase-3 activation $[157,158]$. Thus, viroporins exert extensive effects on ion homeostasis manipulating apoptosis and inflammation signaling. Drugs, siRNA, or shRNA that can inhibit viroporin activity and expression are shown to decrease viral titer in several picornavirus-infected cells [153]. CVB3 and EV71 can additionally regulate miRNAs which has pro-apoptotic effects: CVB3 upregulates miRNA-34a in infected rodent cardiomyocytes [159]. EV71 upregulates let-7b in human neuroblastoma cells [160], and it also upregulates miRNA-146a and downregulates miRNA-370 in human rhabdomyosarcoma cells [161], thus making these miRNAs possible treatment targets. 
In conclusion, enteroviruses can promote anti- and pro-apoptotic signaling. The virus can switch these opposite processes in a time / phase-dependent way: Activation of the intrinsic apoptotic pathway in CVB3-infected HeLa cells and Green Monkey Kidney cells is initiated at later stages of infection [162-164]. Agol et al. observed a pro-apoptotic phase at the very early stage of infection, followed by an anti-apoptotic stage and another switch to pro-apoptotic signaling in the late stage of infection [165]. By sequentially inhibiting or activating cell signaling, viruses can regulate apoptosis at different stages of infection [123]. One way to control this is by gradually increasing cytosolic $\mathrm{Ca}^{2+}$ levels through the expression of viroporins, which is initially pro-survival at moderate $\mathrm{Ca}^{2+}$ levels, but promotes apoptosis at later stages with high cytosolic $\mathrm{Ca}^{2+}$ concentrations. Furthermore, the previously discussed Herp is shown to reduce cytosolic $\mathrm{Ca}^{2+}$ peaks at the early infection stage, in which the cytosolic $\mathrm{Ca}^{2+}$ level is gradually increasing, therefore acting as a switch for $\mathrm{Ca}^{2+}$ level change during a virus life cycle [134]. Moreover, the aforementioned activation of PI3K / Akt survival pathway is observed to primarily occur at the early stage of infection, and only after active replication of poliovirus, apoptosis is promoted due to phosphorylation of JNK [132].

\section{PVB19}

NS1 of PVB19 induces apoptosis in erythroid cells, hepatocytes, and monkey epithelial Cos-7 cells by using its nucleoside triphosphate-binding domain and activating TNF- $\alpha$ and mitochondrial / intrinsic caspase pathways. This is possibly mediated via caspase $3,-6,-8$, and / or -9, p53 and its downstream cell cycle kinase inhibitors p16 $6^{\text {INK4 }}$ and p2 $1^{\text {WAF1/CIP1 }}$ [125$127,166,167]$. Also, the small $11 \mathrm{kDa}$ nonstructural protein (see also section 2) promotes apoptosis in erythroid progenitor cells by activating caspase-10 and there is evidence that this protein may be even more pro-apoptotic than NS1 [24]. Gene expression analysis of EMBs with transcriptionally active PVB19 and clinically suspected cardiomyopathy showed decrease in pro-apoptotic marker Bax [9].

In summary, enteroviruses and PVB19 alter cell death which may be to their advantage. Treatment options could include manipulating apoptosis in favor of the host. In patients, high apoptosis rates in acute myocarditis correlates with progression towards fatal heart failure [168]. Apoptosis is correlated with disease severity while inhibition of apoptosis in virus-induced diseases is overall observed to be beneficial in animal models [169]. Inhibiting CVB3-mediated apoptosis using Phyllaemblicin B reduced myocardial damage in mice, suggesting that apoptosis inhibition could be generally beneficial when it comes to therapeutic applications [170]. In line, activating apoptosis by inhibiting the anti-apoptotic STAT3 pathway showed worsening of ventricular function and correlated with reduced survival in CVB3-induced myocarditis in BALB/c mice [171].

\section{Viral Effects on Energy Metabolism}

\section{CVB3}

Several studies show that the energy metabolism is drastically altered during viral myocarditis. In mice, reduction of mitochondrial ATP/ADP ratio is observed, presumably due to the production of autoantibodies against the adenine nucleotide translocator (ANT), which transports ADP and ATP [172]. A gene array performed for CVB3-induced myopathy in mouse hearts showed that genes involved in mitochondrial oxidative phosphorylation and fatty acid metabolism were downregulated [173]. In mouse atrial cardiomyocytes mitochondrial fragmentation was observed [174]. It can be verified that CVB3 proteins localize to the mitochondria and stimulate dynamin related protein 1 (drp1)-mediated mitochondrial fission which leads to the release of EMVs containing viral progeny and fragmented mitochondrial components. This process can be reversed by inhibiting drp1 e.g. via Mdivi-1, so that EMVs are not extruded. Instead, the EMVs could be released via cytolytic cell death, which could make the virus more vulnerable to neutralizing antibodies. Indeed, 


\section{Cellular Physiology Cell Physiol Biochem 2021;55:679-703 \\ \begin{tabular}{ll|l} 
and Biochemistry $10.33594 / 000000470$ & Published online: 18 November 2021 The Author(s). Published by \\
Cell Physiol Biochem Press GmbH\&Co. KG
\end{tabular}}

Ho et al.: CVB3 and PVB19 in Viral Myocarditis

mice show improved survival rates, reduced mitochondrial dysfunction, and reduced inflammatory cell invasion after drp1 inhibition [174, 175].

The mitochondrial respiratory chain (RC) consists of five complexes that transport electrons while creating a proton gradient which is used to produce ATP. A dysfunction in this chain leads to the misdirection of electrons and the formation of reactive oxygen species (ROS), which cause oxidative stress that damages proteins, lipids, and DNA, resulting in apoptosis [176-178]. Ebermann et al. conducted an analysis on the effects of CVB3 on each complex of the $\mathrm{RC}$, comparing two mouse strains: $C 57 \mathrm{BL} / 6$ mice which are able to rapidly eliminate the virus after an acute phase of infection and recover, therefore being regarded resistant against CVB3, and A.SW/SnJ mice in which CVB3 persists and results in chronic myocarditis [179]. In brief, it was uncovered, that the CVB3-resistant $C 57 B L / 6$ mouse strain had decreased complex IV activity. Interestingly, the activity of complex I and complex III, which are mainly responsible for ROS production, was increased and a higher level of ROS was found compared to the CVB3-premissive mouse strain. Also, the CVB3-resistant mice showed higher expression of Bax, Bcl-2, and caspase-3, which are part of the intrinsic apoptosis mechanism. This can possibly be explained by ROS level elevation. Removal of ROS is shown to be disturbed in $C 57 B L / 6$ mice as catalase, which removes $\mathrm{H}_{2} \mathrm{O}_{2}$, is extremely downregulated. In contrast, in the CVB3-permissive A.SW/SnJ mice all RC complexes were inhibited, which would imply that ATP generation is also reduced. The ROS level is lower possibly due to the less-active RC and activation of ROS-removing enzymes. As a possible consequence, the activation of the intrinsic mitochondrial apoptosis pathway is reduced compared to CVB3-resistant mice. Thus, imbalanced RC, higher ROS level, and apoptosis can correlate with higher virus elimination which stops the transition from acute to chronic infection. In fact, reduction of ROS by a potent antioxidant in CVB3-infected HeLa cells fails to inhibit virus replication [116]. In iPSC-derived ventricular cardiomyocytes that express CVB3 and in patients with acute CVB3 myocarditis, ROS levels and oxidative stress was elevated $[180,181]$. It would be interesting to investigate whether patients with chronic myocarditis exert reduced oxidative stress. Further, elevated expression of the NADPH homologue Nox4 is observed in CVB3-mediated myocarditis in mice. Nox4 induces ROS production and the use of the a non-specific inhibitor of Nox4, diphenyleneiodonium (DPI), is effective in reducing ROS and is having alleviating effects in CVB3-expressing mice [182].

\section{PVB19}

In patients with active and replicative PVB19 in the myocardium, transcriptional deregulation of several genes associated with mitochondrial energy metabolism is observed [9]: Partly in line with the observations concerning enteroviruses, the adenosine nucleotide translocator ANT1, primarily found in heart- and skeletal muscle, is upregulated. Carnitine acyltransferase I (CPT1), which plays an important role in fatty acid transport, is also downregulated. Components of the RC complexes are dysregulated: Some components of complex I i.e. NDUFS2 and NDUSB7 are found downregulated in EMBs with transcriptionally active PVB19 in comparison to virus negative and latent PVB19 EMBs. However, one subunit of complex IV i.e. COX1 was found upregulated and two of complex V i.e ATP5L and ATP5I were upregulated and downregulated respectively. The antioxidative enzyme SOD2, which takes part in cellular ROS removal, is downregulated. In line with the correlation between ROS level and apoptosis, the pro-apoptotic marker Bax is also shown to be downregulated in this study. In summary, patients with transcriptionally active PVB19 have a phenotype partially similar to that of the CVB3-permissive A.SW/SnJ mice [179]: Complex I, that produces ROS, and SOD2 were downregulated, which may indicate a decreased ROS level. Whether ROS level is indeed reduced in PVB19-mediated myocarditis has to be further investigated. ATP production may also be altered due to altered respiratory complex and ATP transporter expression and activity. 


\section{Viral Effects on Ion Channels}

Correct and rhythmic cardiac contraction depends on multiple aspects, most importantly the intracellular $\mathrm{Ca}^{2+}$ cycling and the generation of action potentials (AP), because they play the crucial role in the calcium-dependent excitation-contraction-coupling in the heart [183]. The action potential in the heart is mainly formed by the currents $I_{\mathrm{Na}^{\prime}} I_{\mathrm{to}^{\circ}}, I_{\mathrm{Ca}^{\prime}} I_{\mathrm{Kr}} I_{\mathrm{Ks}^{\prime}}$ and $I_{\mathrm{K} 1}$ which are conducted by cardiac ion channels [184]. A study which analyzed three patient cases with myocarditis suggests that an underlying channelopathy is one possible predisposition for triggering ventricular fibrillation and sudden death after acute myocarditis [185].

\section{CVB3}

Steinke et al. showed in CVB3-expressing Xenopus laevis oocytes that, currents of the cardiac ion channels KCNQ1 (also called Kv7.1) / KCNE1 $\left(I_{\mathrm{KS}}\right)$ are elevated, while the currents of the rapidly activating delayed rectifier potassium channel hERG1 $\left(I_{\mathrm{Kr}}\right)$ and the voltagedependent $\mathrm{Ca}^{2+} \mathrm{L}$-type channel Cav1.2 / a2d1/ b2 $\left(I_{\mathrm{Ca}}\right)$ are reduced. The distribution of these channels in the cardiomyocyte membrane of CVB3-infected mice is altered, too [186]. The CVB3 proteins 2A, 2BC, 3A, and 3B have significant effects on the currents of these three ion channels. At the same time, serum and glucocorticoid-regulated kinase 1 (SGK1) is shown to be elevated, which upregulates the Rab11-dependent transport of vesicles containing ion channels like KCNQ1 / KCNE1, which would explain the enhanced KCNQ1 / KCNE1 localization in the plasma membrane (see Fig. 4C) [187, 188]. SGK1 expression is particularly elevated under stress conditions, which may explain why fibrillations in CVB3 myocarditis patients occur especially after stress or intense body labor [189]. Inhibition of SGK1 in CVB3expressing oocytes leads to reduction of the KCNQ1 / KCNE1 current back to a healthy level, making it an interesting field of future study as a possible therapeutic treatment against pro-arrhythmic events [186]. Yang et al. investigated the effects on ion currents in rodent cardiomyocytes after inoculation with CVB3 as well [190]: The L-type $\mathrm{Ca}^{2+}$ channel current $I_{\mathrm{Ca}}$ and the outward potassium current $I_{\mathrm{Out}}$ increased while inward rectifying potassium $I_{\mathrm{K} 1}$ decreased. They also observed a higher expression of voltage-gated potassium channels i.e. Kv1.2, Kv2.1, and Kv4.2. Upon treatment of CVB3-infected rats with taurine and astragalus membranaceus, the alteration of the currents via CVB3 was prevented, thus qualifying these chemicals as promising treatment strategies.

\section{PVB19}

Ion channel expression and function is also relevant in vascular endothelial cells, which are infected by PVB19. They are associated with cell membrane potential generation, signal transduction, hemodynamics, and vasomotor functions. Therefore, dysfunction of ion channel expression and function can lead to vascular diseases [191]. Recent studies have shown that the VP1 region of PVB19 has a phospholipase A2 (PLA2)-like activity that can produce lysophosphatidylcholine and lysophosphatidic acid [192, 193]. Lysophosphatidylcholine can cause adverse effects on endothelial cells such as enhanced inflammation, disruption of mitochondrial integrity, induction of apoptosis and altered ion channel regulation [194]. This has a major effect on several endothelial ion channels as well. Lysophosphatidylcholine could activate the store-operated or capacitative $\mathrm{Ca}^{2+}$ channel $I_{\mathrm{CRAC}}$ in human endothelial cells, thus leading to accelerated increase of $\mathrm{Ca}^{2+}$ entry, which is important for endothelial vasodilation [195, 196]. Lysophosphatidic acid has a plethora of effects on ion channels including T-type $\mathrm{Ca}^{2+}$ channels and inward rectifier $\mathrm{K}^{+}$and Calcium-activated $\mathrm{K}^{+}$channels $\left(\mathrm{IK}_{\mathrm{Ca}}\right)$ that are relevant in cardiovascular endothelial cells [191, 193]. Secondly, PLA2-like activity of VP1 upregulates the activity of epithelial $\mathrm{Na}^{+}$channel ENaC which results in early swelling and later stiffening of the vascular endothelium [197]. Thirdly, downregulation of potassium channels such as Kv1.3, Kv1.5, Kir2.1 channels and inhibition of the $\mathrm{Na}^{+} / \mathrm{K}^{+}$ATPase activity by VP1 leads to cell swelling and thus contributes to endothelial dysfunction $[198,199]$. PLA2 also appears to be relevant for efficient transfer of the viral genome from 
lysosomes and endosomes into the nucleus for viral replication [200]. Hence, the study and development of phospholipase inhibitors as antiviral drugs against PVB19 infection could be beneficial for patient treatment.

\section{Conclusion}

In summary, PVB19 and enteroviruses can affect the host cells in terms of host immune system, ECM remodeling, replication, apoptosis, autophagy, energy metabolism, ion channels, and ion conductivity (see Fig. 3 and 4). To this date there are no effective treatment strategies against viral myocarditis, but in-vitro studies, animal models, and clinical trials show promising treatment targets which should be pursued further. Especially with emerging viruses such as SARS-CoV-2 which may have detrimental cardiac effects and can also cause myocarditis, it is highly relevant to find new treatment strategies against VMC [201]. To better understand the viral mechanisms and find new treatments, good disease models that resemble viral diseases in humans are also of great importance. In-vitro models for CVB3induced myocarditis using commonly used cell lines i.e. HeLa-cells, HL-1, and H9c2 and iCell ${ }^{\circledR}$ Cardiomyocytes were shown to differ between each other after CVB3 infection regarding permissiveness, infection pattern, and mode of cell death. Therefore, in-vitro studies with commonly used cell lines have to be further evaluated whether they authentically represent the CVB3 pathogenesis. Amongst the compared cell lines, iCell ${ }^{\circledR}$ Cardiomyocytes were found to be the most suitable infection model. Infection rates were significantly higher compared to other cell lines with rates at about $100 \%$. Cells were homogenously infected, and infected cells resembled CVB3-infected mouse hearts morphologically [202]. Another CVB3-iPS cell model recently published by Peischard et al. is also a promising disease model to analyze the effect of CVB3 in possibly any kind of cells in-vitro in a more controlled manner due to the implemented Tet-On system [181].

\section{Acknowledgements}

\section{Funding}

This research was funded by Deutsche Forschungsgemeinschaft (DFG) under grant number DFG Se1077/13-1 to G.S.

\section{Disclosure Statement}

The authors declare that no conflict of interests exist.

\section{References}

1 Esfandiarei M, McManus BM: Molecular biology and pathogenesis of viral myocarditis. Annu Rev Pathol 2008;3:127-155.

2 Caforio AL, Pankuweit S, Arbustini E, Basso C, Gimeno-Blanes J, Felix SB, Fu M, Heliö T, Heymans S, Jahns R, Klingel K, Linhart A, Maisch B, McKenna W, Mogensen J, Pinto YM, Ristic A, Schultheiss HP, Seggewiss $\mathrm{H}$, Tavazzi L, et al.: Current state of knowledge on aetiology, diagnosis, management, and therapy of myocarditis: a position statement of the European Society of Cardiology Working Group on Myocardial and Pericardial Diseases. Eur Heart J 2013;34:2636-2648, 2648a-2648d.

3 Caforio AL, Calabrese F, Angelini A, Tona F, Vinci A, Bottaro S, Ramondo A, Carturan E, Iliceto S, Thiene G, Daliento L: A prospective study of biopsy-proven myocarditis: prognostic relevance of clinical and aetiopathogenetic features at diagnosis. Eur Heart J 2007;28:1326-1333. 
Ho et al.: CVB3 and PVB19 in Viral Myocarditis

4 Dadashi M, Azimi T, Faghihloo E: Global study of viral myocarditis: A systematic review and meta-analysis. J Acute Dis 2020;9:1.

5 Verdonschot J, Hazebroek M, Merken J, Debing Y, Dennert R, Brunner-La Rocca HP, Heymans S: Relevance of cardiac parvovirus B19 in myocarditis and dilated cardiomyopathy: review of the literature. Eur J Heart Fail 2016;18:1430-1441.

6 Bock CT, Klingel K, Kandolf R: Human parvovirus B19-associated myocarditis. N Engl J Med 2010;362:12481249.

7 Callon D, Berri F, Lebreil AL, Fornès P, Andreoletti L: Coinfection of Parvovirus B19 with Influenza A/H1N1 Causes Fulminant Myocarditis and Pneumonia. An Autopsy Case Report. Pathogens 2021;10:958.

8 Das BB, Prusty BK, Niu J, Huang ML, Zhu H, Eliassen E, Kuypers JM, Jerome KR: Detection of parvovirus B19 and human herpesvirus 6 in pediatric dilated cardiomyopathy: Impact after heart transplantation. Ann Pediatr Cardiol 2020;13:301-308.

9 Kuhl U, Lassner D, Dorner A, Rohde M, Escher F, Seeberg B, Hertel E, Tschope C, Skurk C, Gross UM, Schultheiss HP, Poller W: A distinct subgroup of cardiomyopathy patients characterized by transcriptionally active cardiotropic erythrovirus and altered cardiac gene expression. Basic Res Cardiol 2013;108:372.

10 Pollack A, Kontorovich AR, Fuster V, Dec GW: Viral myocarditis--diagnosis, treatment options, and current controversies. Nat Rev Cardiol 2015;12:670-680.

11 Tschöpe C, Cooper LT, Torre-Amione G, Van Linthout S: Management of Myocarditis-Related Cardiomyopathy in Adults. Circ Res 2019;124:1568-1583.

12 Gelderblom HR: Structure and Classification of Viruses (Chapter 41); in Baron S (eds): Medical Microbiology. 4th ed. Galveston (TX), University of Texas Medical Branch at Galveston, 1996.

13 Jirasko V, Montserret R, Lee JY, Gouttenoire J, Moradpour D, Penin F, Bartenschlager R: Structural and functional studies of nonstructural protein 2 of the hepatitis $C$ virus reveal its key role as organizer of virion assembly. PLoS Pathog 2010;6:e1001233.

14 Zhi N, Zádori Z, Brown KE, Tijssen P: Construction and sequencing of an infectious clone of the human parvovirus B19. Virology 2004;318:142-152.

15 Bowles NE, Richardson PJ, Olsen EG, Archard LC: Detection of Coxsackie-B-virus-specific RNA sequences in myocardial biopsy samples from patients with myocarditis and dilated cardiomyopathy. Lancet 1986;1:1120-1123.

16 Lindberg AM, Stålhandske PO, Pettersson U: Genome of coxsackievirus B3. Virology 1987;156:50-63.

17 Buenz EJ, Howe CL: Picornaviruses and cell death. Trends Microbiol 2006;14:28-36.

18 Nayak A, Goodfellow IG, Belsham GJ: Factors required for the Uridylylation of the foot-and-mouth disease virus 3B1, 3B2, and 3B3 peptides by the RNA-dependent RNA polymerase (3Dpol) in vitro. J Virol 2005;79:7698-7706.

19 Yang Y, Wang Z: IRES-mediated cap-independent translation, a path leading to hidden proteome. J Mol Cell Biol 2019;11:911-919.

20 Qiu J, Söderlund-Venermo M, Young NS: Human Parvoviruses. Clin Microbiol Rev 2017;30:43-113.

21 Ozawa K, Young N: Characterization of capsid and noncapsid proteins of B19 parvovirus propagated in human erythroid bone marrow cell cultures. J Virol 1987;61:2627-2630.

22 Ganaie SS, Qiu J: Recent Advances in Replication and Infection of Human Parvovirus B19. Front Cell Infect Microbiol 2018;8:166.

23 Pillet S, Annan Z, Fichelson S, Morinet F: Identification of a nonconventional motif necessary for the nuclear import of the human parvovirus B19 major capsid protein (VP2). Virology 2003;306:25-32.

24 Chen AY, Zhang EY, Guan W, Cheng F, Kleiboeker S, Yankee TM, Qiu J: The small 11 kDa nonstructural protein of human parvovirus B19 plays a key role in inducing apoptosis during B19 virus infection of primary erythroid progenitor cells. Blood 2010;115:1070-1080.

25 Cotmore SF, McKie VC, Anderson LJ, Astell CR, Tattersall P: Identification of the major structural and nonstructural proteins encoded by human parvovirus B19 and mapping of their genes by procaryotic expression of isolated genomic fragments. J Virol 1986;60:548-557.

26 Bültmann BD, Klingel K, Sotlar K, Bock CT, Baba HA, Sauter M, Kandolf R: Fatal parvovirus B19-associated myocarditis clinically mimicking ischemic heart disease: an endothelial cell-mediated disease. Hum Pathol 2003;34:92-95.

27 Favere K, Bosman M, Klingel K, Heymans S, Van Linthout S, Delputte PL, De Sutter J, Heidbuchel H, Guns PJ: Toll-Like Receptors: Are They Taking a Toll on the Heart in Viral Myocarditis? Viruses 2021;13:1003. 
28 Bergelson JM, Krithivas A, Celi L, Droguett G, Horwitz MS, Wickham T, Crowell RL, Finberg RW: The murine CAR homolog is a receptor for coxsackie B viruses and adenoviruses. J Virol 1998;72:415-419.

29 Shafren DR, Williams DT, Barry RD: A decay-accelerating factor-binding strain of coxsackievirus B3 requires the coxsackievirus-adenovirus receptor protein to mediate lytic infection of rhabdomyosarcoma cells. J Virol 1997;71:9844-9848.

30 Pinkert S, Westermann D, Wang X, Klingel K, Dörner A, Savvatis K, Grössl T, Krohn S, Tschöpe C, Zeichhardt H, Kotsch K, Weitmann K, Hoffmann W, Schultheiss HP, Spiller OB, Poller W, Fechner H: Prevention of cardiac dysfunction in acute coxsackievirus B3 cardiomyopathy by inducible expression of a soluble coxsackievirus-adenovirus receptor. Circulation 2009;120:2358-2366.

31 Yanagawa B, Spiller OB, Choy J, Luo H, Cheung P, Zhang HM, Goodfellow IG, Evans DJ, Suarez A, Yang D, McManus BM: Coxsackievirus B3-associated myocardial pathology and viral load reduced by recombinant soluble human decay-accelerating factor in mice. Lab Invest 2003;83:75-85.

32 Brown KE, Anderson SM, Young NS: Erythrocyte P antigen: cellular receptor for B19 parvovirus. Science 1993;262:114-117.

33 Bieri J, Ros C: Globoside Is Dispensable for Parvovirus B19 Entry but Essential at a Postentry Step for Productive Infection. J Virol 2019;93:e00972-19.

34 Okuda T, Nakakita S, Nakayama K: Structural characterization and dynamics of globotetraosylceramide in vascular endothelial cells under TNF-alpha stimulation. Glycoconj J 2010;27:287-296.

35 Munakata Y, Saito-Ito T, Kumura-Ishii K, Huang J, Kodera T, Ishii T, Hirabayashi Y, Koyanagi Y, Sasaki T: Ku80 autoantigen as a cellular coreceptor for human parvovirus B19 infection. Blood 2005;106:3449-3456.

36 Weigel-Kelley KA, Yoder MC, Srivastava A: Alpha5beta1 integrin as a cellular coreceptor for human parvovirus B19: requirement of functional activation of beta1 integrin for viral entry. Blood 2003;102:3927-3933.

37 von Kietzell K, Pozzuto T, Heilbronn R, Grössl T, Fechner H, Weger S: Antibody-mediated enhancement of parvovirus B19 uptake into endothelial cells mediated by a receptor for complement factor C1q. J Virol 2014;88:8102-8115.

38 Munakata Y, Kato I, Saito T, Kodera T, Ishii KK, Sasaki T: Human parvovirus B19 infection of monocytic cell line U937 and antibody-dependent enhancement. Virology 2006;345:251-257.

39 Badorff C, Lee GH, Lamphear BJ, Martone ME, Campbell KP, Rhoads RE, Knowlton KU: Enteroviral protease 2A cleaves dystrophin: evidence of cytoskeletal disruption in an acquired cardiomyopathy. Nat Med 1999;5:320-326.

40 Kandolf R, Ameis D, Kirschner P, Canu A, Hofschneider PH: In situ detection of enteroviral genomes in myocardial cells by nucleic acid hybridization: an approach to the diagnosis of viral heart disease. Proc Natl Acad Sci U S A 1987;84:6272-6276.

41 Mann DL: The emerging role of innate immunity in the heart and vascular system: for whom the cell tolls. Circ Res 2011;108:1133-1145.

42 Corsten MF, Schroen B, Heymans S: Inflammation in viral myocarditis: friend or foe? Trends Mol Med 2012;18:426-437.

43 Xu M, Li X, Song L, Tao C, Fang J, Tao L: Lupeol alleviates coxsackievirus B3-induced viral myocarditis in mice via downregulating toll-like receptor 4. J Int Med Res 2020;48:300060520910908.

44 Fei Y, Chaulagain A, Wang T, Chen Y, Liu J, Yi M, Wang Y, Huang Y, Lin L, Chen S, Xu W, Tong L, Wu X, Zhao D, Zhang F, Zhao W, Zhong Z: MiR-146a down-regulates inflammatory response by targeting TLR3 and TRAF6 in Coxsackievirus B infection. RNA 2020;26:91-100.

45 Nie S, Dong B, Gao S, Zhou Y, Lu W, Fang M, Hua S, Yu Y, Wang L: The protective effect of interfering TLR9IRF5 signaling pathway on the development of CVB3-induced myocarditis. Clin Immunol 2019;207:24-35.

46 Kraft L, Erdenesukh T, Sauter M, Tschöpe C, Klingel K: Blocking the IL-1 $\beta$ signalling pathway prevents chronic viral myocarditis and cardiac remodeling. Basic Res Cardiol 2019;114:11.

47 Wang YX, da Cunha V, Vincelette J, White K, Velichko S, Xu Y, Gross C, Fitch RM, Halks-Miller M, Larsen BR, Yajima T, Knowlton KU, Vergona R, Sullivan ME, Croze E: Antiviral and myocyte protective effects of murine interferon-beta and -\{alpha\}2 in coxsackievirus B3-induced myocarditis and epicarditis in Balb/c mice. Am J Physiol Heart Circ Physiol 2007;293:H69-76.

48 Heim A, Weiss S: Interferons in enteroviral heart disease: modulation of cytokine expression and antiviral activity. Med Microbiol Immunol 2004;193:149-154. 


\section{Cellular Physiology Cell Physiol Biochem 2021;55:679-703 \begin{tabular}{ll|l} 
and Biochemistry & DOl: 10.33594/000000470 & $\begin{array}{l}\text { P 2021 The Author(s). Published by } \\
\text { Published online: 18 November } 2021 \\
\text { Cell Physiol Biochem Press GmbH\&Co. KG }\end{array}$ \\
\cline { 2 - 3 }
\end{tabular}}

Ho et al.: CVB3 and PVB19 in Viral Myocarditis

49 Kühl U, Pauschinger M, Schwimmbeck PL, Seeberg B, Lober C, Noutsias M, Poller W, Schultheiss HP: Interferon-beta treatment eliminates cardiotropic viruses and improves left ventricular function in patients with myocardial persistence of viral genomes and left ventricular dysfunction. Circulation 2003;107:27932798.

50 Kuhl U, Lassner D, von Schlippenbach J, Poller W, Schultheiss HP: Interferon-Beta improves survival in enterovirus-associated cardiomyopathy. J Am Coll Cardiol 2012;60:1295-1296.

51 Horwitz MS, La Cava A, Fine C, Rodriguez E, Ilic A, Sarvetnick N: Pancreatic expression of interferon-gamma protects mice from lethal coxsackievirus B3 infection and subsequent myocarditis. Nat Med 2000;6:693697.

52 Wessely R, Klingel K, Knowlton KU, Kandolf R: Cardioselective infection with coxsackievirus B3 requires intact type I interferon signaling: implications for mortality and early viral replication. Circulation 2001;103:756-761.

53 Yasukawa H, Yajima T, Duplain H, Iwatate M, Kido M, Hoshijima M, Weitzman MD, Nakamura T, Woodard S, Xiong D, Yoshimura A, Chien KR, Knowlton KU: The suppressor of cytokine signaling-1 (SOCS1) is a novel therapeutic target for enterovirus-induced cardiac injury. J Clin Invest 2003;111:469-478.

54 Yajima T, Yasukawa H, Jeon ES, Xiong D, Dorner A, Iwatate M, Nara M, Zhou H, Summers-Torres D, Hoshijima M, Chien KR, Yoshimura A, Knowlton KU: Innate defense mechanism against virus infection within the cardiac myocyte requiring gp130-STAT3 signaling. Circulation 2006;114:2364-2373.

55 Lane JR, Neumann DA, Lafond-Walker A, Herskowitz A, Rose NR: Interleukin 1 or tumor necrosis factor can promote Coxsackie B3-induced myocarditis in resistant B10.A mice. J Exp Med 1992;175:1123-1129.

56 Huang CH, Vallejo JG, Kollias G, Mann DL: Role of the innate immune system in acute viral myocarditis. Basic Res Cardiol 2009;104:228-237.

57 Wada H, Saito K, Kanda T, Kobayashi I, Fujii H, Fujigaki S, Maekawa N, Takatsu H, Fujiwara H, Sekikawa K, Seishima M: Tumor necrosis factor-alpha (TNF-alpha) plays a protective role in acute viralmyocarditis in mice: A study using mice lacking TNF-alpha. Circulation 2001;103:743-749.

58 Godeny EK, Gauntt CJ: Involvement of natural killer cells in coxsackievirus B3-induced murine myocarditis. J Immunol 1986;137:1695-1702.

59 Klingel K, Fabritius C, Sauter M, Göldner K, Stauch D, Kandolf R, Ettischer N, Gahlen S, Schönberger T, Ebner S, Makrigiannis AP, Bélanger S, Diefenbach A, Polić B, Pratschke J, Kotsch K: The activating receptor NKG2D of natural killer cells promotes resistance against enterovirus-mediated inflammatory cardiomyopathy. J Pathol 2014;234:164-177.

60 Hirasawa K, Tsutsui S, Takeda M, Mizutani M, Itagaki S, Doi K: Depletion of Mac1-positive macrophages protects DBA/2 mice from encephalomyocarditis virus-induced myocarditis and diabetes. J Gen Virol 1996;77:737-741.

61 Yang X, Yue Y, Xiong S: Dpep2 Emerging as a Modulator of Macrophage Inflammation Confers Protection Against CVB3-Induced Viral Myocarditis. Front Cell Infect Microbiol 2019;9:57.

62 Papageorgiou AP, Heymans S: Interactions between the extracellular matrix and inflammation during viral myocarditis. Immunobiology 2012;217:503-510.

63 Page-McCaw A, Ewald AJ, Werb Z: Matrix metalloproteinases and the regulation of tissue remodelling. Nat Rev Mol Cell Biol 2007;8:221-233.

64 Westermann D, Savvatis K, Schultheiss HP, Tschöpe C: Immunomodulation and matrix metalloproteinases in viral myocarditis. J Mol Cell Cardiol 2010;48:468-473.

65 Heymans S, Pauschinger M, De Palma A, Kallwellis-Opara A, Rutschow S, Swinnen M, Vanhoutte D, Gao F, Torpai R, Baker AH, Padalko E, Neyts J, Schultheiss HP, Van de Werf F, Carmeliet P, Pinto YM: Inhibition of urokinase-type plasminogen activator or matrix metalloproteinases prevents cardiac injury and dysfunction during viral myocarditis. Circulation 2006;114:565-573.

66 Pauschinger M, Rutschow S, Chandrasekharan K, Westermann D, Weitz A, Peter Schwimmbeck L, Zeichhardt H, Poller W, Noutsias M, Li J, Schultheiss HP, Tschope C: Carvedilol improves left ventricular function in murine coxsackievirus-induced acute myocarditis association with reduced myocardial interleukin-1beta and MMP-8 expression and a modulated immune response. Eur J Heart Fail 2005;7:444452.

67 Cheung C, Marchant D, Walker EK, Luo Z, Zhang J, Yanagawa B, Rahmani M, Cox J, Overall C, Senior RM, Luo H, McManus BM: Ablation of matrix metalloproteinase-9 increases severity of viral myocarditis in mice. Circulation 2008;117:1574-1582. 
68 Westermann D, Savvatis K, Lindner D, Zietsch C, Becher PM, Hammer E, Heimesaat MM, Bereswill S, Völker U, Escher F, Riad A, Plendl J, Klingel K, Poller W, Schultheiss HP, Tschöpe C: Reduced degradation of the chemokine MCP-3 by matrix metalloproteinase-2 exacerbates myocardial inflammation in experimental viral cardiomyopathy. Circulation 2011;124:2082-2093.

69 Schmidt-Lucke C, Spillmann F, Bock T, Kühl U, Van Linthout S, Schultheiss HP, Tschöpe C: Interferon beta modulates endothelial damage in patients with cardiac persistence of human parvovirus b19 infection. J Infect Dis 2010;201:936-945.

70 Schultheiss HP, Piper C, Sowade O, Waagstein F, Kapp JF, Wegscheider K, Groetzbach G, Pauschinger M, Escher F, Arbustini E, Siedentop H, Kuehl U: Betaferon in chronic viral cardiomyopathy (BICC) trial: Effects of interferon- $\beta$ treatment in patients with chronic viral cardiomyopathy. Clin Res Cardiol 2016;105:763773.

71 Klingel K, Hohenadl C, Canu A, Albrecht M, Seemann M, Mall G, Kandolf R: Ongoing enterovirus-induced myocarditis is associated with persistent heart muscle infection: quantitative analysis of virus replication, tissue damage, and inflammation. Proc Natl Acad Sci U S A 1992;89:314-318.

72 Klingel K, Rieger P, Mall G, Selinka HC, Huber M, Kandolf R: Visualization of enteroviral replication in myocardial tissue by ultrastructural in situ hybridization: identification of target cells and cytopathic effects. Lab Invest 1998;78:1227-1237.

73 Kaya Z, Leib C, Katus HA: Autoantibodies in heart failure and cardiac dysfunction. Circ Res 2012;110:145158.

74 Felix SB, Staudt A: Non-specific immunoadsorption in patients with dilated cardiomyopathy: mechanisms and clinical effects. Int J Cardiol 2006;112:30-33.

75 Staudt A, Hummel A, Ruppert J, Dörr M, Trimpert C, Birkenmeier K, Krieg T, Staudt Y, Felix SB: Immunoadsorption in dilated cardiomyopathy: 6-month results from a randomized study. Am Heart J 2006;152:712.e711-716.

76 Doesch A0, Mueller S, Nelles M, Konstandin M, Celik S, Frankenstein L, Goeser S, Kaya Z, Koch A, Zugck C, Katus HA: Impact of troponin I-autoantibodies in chronic dilated and ischemic cardiomyopathy. Basic Res Cardiol 2011;106:25-35.

77 Yuan J, Yu M, Lin QW, Cao AL, Yu X, Dong JH, Wang JP, Zhang JH, Wang M, Guo HP, Cheng X, Liao YH: Th17 cells contribute to viral replication in coxsackievirus B3-induced acute viral myocarditis. J Immunol 2010;185:4004-4010.

78 Yuan J, Yu M, Lin QW, Cao AL, Yu X, Dong JH, Wang JP, Zhang JH, Wang M, Guo HP, Liao YH: Neutralization of IL-17 inhibits the production of anti-ANT autoantibodies in CVB3-induced acute viral myocarditis. Int Immunopharmacol 2010;10:272-276.

79 Myers JM, Cooper LT, Kem DC, Stavrakis S, Kosanke SD, Shevach EM, Fairweather D, Stoner JA, Cox CJ, Cunningham MW: Cardiac myosin-Th17 responses promote heart failure in human myocarditis. JCI Insight 2016;1:e85851.

80 Wei H, Lin CK, Lu SJ, Wen YX, Yuan S, Liu YL: CD11b is involved in coxsackievirus B3-induced viral myocarditis in mice by inducing Th17 cells. Open Life Sci 2020;15:1024-1032.

81 Pappritz K, Savvatis K, Miteva K, Kerim B, Dong F, Fechner H, Müller I, Brandt C, Lopez B, González A, Ravassa S, Klingel K, Diez J, Reinke P, Volk HD, Van Linthout S, Tschöpe C: Immunomodulation by adoptive regulatory T-cell transfer improves Coxsackievirus B3-induced myocarditis. FASEB J 2018; DOI: 10.1096/ fj.201701408R.

82 Koch M, Savvatis K, Scheeler M, Dhayat S, Bonaventura K, Pohl T, Riad A, Bulfone-Paus S, Schultheiss HP, Tschöpe C: Immunosuppression with an interleukin-2 fusion protein leads to improved LV function in experimental ischemic cardiomyopathy. Int Immunopharmacol 2010;10:207-212.

83 Miteva K, Pappritz K, El-Shafeey M, Dong F, Ringe J, Tschöpe C, Van Linthout S: Mesenchymal Stromal Cells Modulate Monocytes Trafficking in Coxsackievirus B3-Induced Myocarditis. Stem Cells Transl Med 2017;6:1249-1261.

84 Dominguez F, Kuhl U, Pieske B, Garcia-Pavia P, Tschope C: Update on Myocarditis and Inflammatory Cardiomyopathy: Reemergence of Endomyocardial Biopsy. Rev Esp Cardiol (Engl Ed) 2016;69:178-187.

85 Bujak M, Frangogiannis NG: The role of TGF-beta signaling in myocardial infarction and cardiac remodeling. Cardiovasc Res 2007;74:184-195. 


\section{Cellular Physiology Cell Physiol Biochem 2021;55:679-703 \begin{tabular}{ll|l} 
and Biochemistry $10.33594 / 000000470$ & C 2021 The Author(s). Published by \\
Published online: 18 November 2021 & Cell Physiol Biochem Press GmbH\&Co. KG
\end{tabular}}

Ho et al.: CVB3 and PVB19 in Viral Myocarditis

86 Kania G, Blyszczuk P, Stein S, Valaperti A, Germano D, Dirnhofer S, Hunziker L, Matter CM, Eriksson U: Heart-infiltrating prominin-1+/CD133+ progenitor cells represent the cellular source of transforming growth factor beta-mediated cardiac fibrosis in experimental autoimmune myocarditis. Circ Res 2009;105:462-470.

87 Kania G, Blyszczuk P, Eriksson U: Mechanisms of cardiac fibrosis in inflammatory heart disease. Trends Cardiovasc Med 2009;19:247-252.

88 Stallion A, Rafferty JF, Warner BW, Ziegler MM, Ryckman FC: Myocardial calcification: a predictor of poor outcome for myocarditis treated with extracorporeal life support. J Pediatr Surg 1994;29:492-494.

89 Cooper LT: Myocarditis. N Engl J Med 2009;360:1526-1538.

90 Tschöpe C, Ammirati E, Bozkurt B, Caforio ALP, Cooper LT, Felix SB, Hare JM, Heidecker B, Heymans S, Hübner N, Kelle S, Klingel K, Maatz H, Parwani AS, Spillmann F, Starling RC, Tsutsui H, Seferovic P, Van Linthout S: Myocarditis and inflammatory cardiomyopathy: current evidence and future directions. Nat Rev Cardiol 2021;18:169-193.

91 Sinagra G, Porcari A, Gentile P, Artico J, Fabris E, Bussani R, Merlo M: Viral presence-guided immunomodulation in lymphocytic myocarditis: an update. Eur J Heart Fail 2021;23:211-216.

92 Tschöpe C, Van Linthout S, Jäger S, Arndt R, Trippel T, Müller I, Elsanhoury A, Rutschow S, Anker SD, Schultheiss HP, Pauschinger M, Spillmann F, Pappritz K: Modulation of the acute defence reaction by eplerenone prevents cardiac disease progression in viral myocarditis. ESC Heart Fail 2020;7:2838-2852.

93 Lee WS, Erdelyi K, Matyas C, Mukhopadhyay P, Varga ZV, Liaudet L, Haskú G, Čiháková D, Mechoulam R, Pacher P: Cannabidiol Limits T Cell-Mediated Chronic Autoimmune Myocarditis: Implications to Autoimmune Disorders and Organ Transplantation. Mol Med 2016;22:136-146.

94 Kazatchkine MD, Kaveri SV: Immunomodulation of autoimmune and inflammatory diseases with intravenous immune globulin. N Engl J Med 2001;345:747-755.

95 Hazebroek MR, Henkens MTHM, Raafs AG, Verdonschot JAJ, Merken JJ, Dennert RM, Eurlings C, Abdul Hamid MA, Wolffs PFG, Winkens B, Brunner-La Rocca HP, Knackstedt C, van Paassen P, van Empel VPM, Heymans SRB: Intravenous immunoglobulin therapy in adult patients with idiopathic chronic cardiomyopathy and cardiac parvovirus B19 persistence: a prospective, double-blind, randomized, placebo-controlled clinical trial. Eur J Heart Fail 2021;23:302-309.

96 Mohamud Y, Shi J, Qu J, Poon T, Xue YC, Deng H, Zhang J, Luo H: Enteroviral Infection Inhibits Autophagic Flux via Disruption of the SNARE Complex to Enhance Viral Replication. Cell Rep 2018;22:3292-3303.

97 Huang L, Yue J: The interplay of autophagy and enterovirus. Semin Cell Dev Biol 2020;101:12-19.

98 Robinson SM, Tsueng G, Sin J, Mangale V, Rahawi S, McIntyre LL, Williams W, Kha N, Cruz C, Hancock BM, Nguyen DP, Sayen MR, Hilton BJ, Doran KS, Segall AM, Wolkowicz R, Cornell CT, Whitton JL, Gottlieb RA, Feuer R: Coxsackievirus B exits the host cell in shed microvesicles displaying autophagosomal markers. PLoS Pathog 2014;10:e1004045.

99 Wong J, Zhang J, Si X, Gao G, Mao I, McManus BM, Luo H: Autophagosome supports coxsackievirus B3 replication in host cells. J Virol 2008;82:9143-9153.

100 Tabor-Godwin JM, Tsueng G, Sayen MR, Gottlieb RA, Feuer R: The role of autophagy during coxsackievirus infection of neural progenitor and stem cells. Autophagy 2012;8:938-953.

101 van der Schaar HM, Melia CE, van Bruggen JA, Strating JR, van Geenen ME, Koster AJ, Bárcena M, van Kuppeveld FJ: Illuminating the Sites of Enterovirus Replication in Living Cells by Using a Split-GFP-Tagged Viral Protein. mSphere 2016;1:e00104-16.

102 Jackson WT, Giddings TH, Taylor MP, Mulinyawe S, Rabinovitch M, Kopito RR, Kirkegaard K: Subversion of cellular autophagosomal machinery by RNA viruses. PLoS Biol 2005;3:e156.

103 Harak C, Lohmann V: Ultrastructure of the replication sites of positive-strand RNA viruses. Virology 2015;479-480:418-433.

104 Wolff G, Melia CE, Snijder EJ, Bárcena M: Double-Membrane Vesicles as Platforms for Viral Replication. Trends Microbiol 2020;28:1022-1033.

105 Kirkegaard K, Jackson WT: Topology of double-membraned vesicles and the opportunity for non-lytic release of cytoplasm. Autophagy 2005;1:182-184.

106 Li X, Wang M, Cheng A, Wen X, Ou X, Mao S, Gao Q Sun D, Jia R, Yang Q, Wu Y, Zhu D, Zhao X, Chen S, Liu M, Zhang S, Liu Y, Yu Y, Zhang L, Tian B, et al.: Enterovirus Replication Organelles and Inhibitors of Their Formation. Front Microbiol 2020;11:1817. 


\section{Cellular Physiology Cell Physiol Biochem 2021;55:679-703 \begin{tabular}{ll|l} 
and Biochemistry & DOl: 10.33594/000000470 & $\begin{array}{l}\text { P 2021 The Author(s). Published by } \\
\text { Published online: 18 November } 2021 \\
\text { Cell Physiol Biochem Press GmbH\&Co. KG }\end{array}$ \\
\cline { 2 - 3 }
\end{tabular}}

Ho et al.: CVB3 and PVB19 in Viral Myocarditis

107 Limpens RW, van der Schaar HM, Kumar D, Koster AJ, Snijder EJ, van Kuppeveld FJ, Bárcena M: The transformation of enterovirus replication structures: a three-dimensional study of single- and doublemembrane compartments. mBio 2011;2:e00166-11.

108 Melia CE, Peddie CJ, de Jong AWM, Snijder EJ, Collinson LM, Koster AJ, van der Schaar HM, van Kuppeveld FJM, Bárcena M: Origins of Enterovirus Replication Organelles Established by Whole-Cell Electron Microscopy. mBio 2019;10:e00951-19.

109 Suhy DA, Giddings TH, Kirkegaard K: Remodeling the endoplasmic reticulum by poliovirus infection and by individual viral proteins: an autophagy-like origin for virus-induced vesicles. J Virol 2000;74:8953-8965.

110 Alirezaei M, Flynn CT, Wood MR, Harkins S, Whitton JL: Coxsackievirus can exploit LC3 in both autophagydependent and -independent manners in vivo. Autophagy 2015;11:1389-1407.

111 Melia CE, van der Schaar HM, Lyoo H, Limpens RWAL, Feng Q, Wahedi M, Overheul GJ, van Rij RP, Snijder EJ, Koster AJ, Bárcena M, van Kuppeveld FJM: Escaping Host Factor PI4KB Inhibition: Enterovirus Genomic RNA Replication in the Absence of Replication Organelles. Cell Rep 2017;21:587-599.

112 Xie W, Wang L, Dai Q, Yu H, He X, Xiong J, Sheng H, Zhang D, Xin R, Qi Y, Hu F, Guo S, Zhang K: Activation of AMPK restricts coxsackievirus B3 replication by inhibiting lipid accumulation. J Mol Cell Cardiol 2015;85:155-167.

113 Feuer R, Pagarigan RR, Harkins S, Liu F, Hunziker IP, Whitton JL: Coxsackievirus targets proliferating neuronal progenitor cells in the neonatal CNS. J Neurosci 2005;25:2434-2444.

114 Luo H, Zhang J, Dastvan F, Yanagawa B, Reidy MA, Zhang HM, Yang D, Wilson JE, McManus BM: Ubiquitindependent proteolysis of cyclin D1 is associated with coxsackievirus-induced cell growth arrest. J Virol 2003;77:1-9.

115 Luo H, Zhang J, Cheung C, Suarez A, McManus BM, Yang D: Proteasome inhibition reduces coxsackievirus B3 replication in murine cardiomyocytes. Am J Pathol 2003;163:381-385.

116 Si X, McManus BM, Zhang J, Yuan J, Cheung C, Esfandiarei M, Suarez A, Morgan A, Luo H: Pyrrolidine dithiocarbamate reduces coxsackievirus B3 replication through inhibition of the ubiquitin-proteasome pathway. J Virol 2005;79:8014-8023.

117 Wang Y, Zhao S, Chen Y, Wang T, Dong C, Wo X, Zhang J, Dong Y, Xu W, Feng X, Qu C, Wang Y, Zhong Z, Zhao W: The Capsid Protein VP1 of Coxsackievirus B Induces Cell Cycle Arrest by Up-Regulating Heat Shock Protein 70. Front Microbiol 2019;10:1633.

118 Feuer R, Mena I, Pagarigan R, Slifka MK, Whitton JL: Cell cycle status affects coxsackievirus replication, persistence, and reactivation in vitro. J Virol 2002;76:4430-4440.

119 Tewary SK, Zhao H, Deng X, Qiu J, Tang L: The human parvovirus B19 non-structural protein 1 N-terminal domain specifically binds to the origin of replication in the viral DNA. Virology 2014;449:297-303.

120 Xu P, Ganaie SS, Wang X, Wang Z, Kleiboeker S, Horton NC, Heier RF, Meyers MJ, Tavis JE, Qiu J: Endonuclease Activity Inhibition of the NS1 Protein of Parvovirus B19 as a Novel Target for Antiviral Drug Development. Antimicrob Agents Chemother 2019;63:e01879-18.

121 Luo Y, Kleiboeker S, Deng X, Qiu J: Human parvovirus B19 infection causes cell cycle arrest of human erythroid progenitors at late $S$ phase that favors viral DNA replication. J Virol 2013;87:12766-12775.

122 Baggen J, Thibaut HJ, Strating JRPM, van Kuppeveld FJM: The life cycle of non-polio enteroviruses and how to target it. Nat Rev Microbiol 2018;16:368-381.

123 Lai Y, Wang M, Cheng A, Mao S, Ou X, Yang Q Wu Y, Jia R, Liu M, Zhu D, Chen S, Zhang S, Zhao XX, Huang J, Gao Q Wang Y, Xu Z, Chen Z, Zhu L, Luo Q, et al.: Regulation of Apoptosis by Enteroviruses. Front Microbiol 2020;11:1145.

124 Croft SN, Walker EJ, Ghildyal R: Picornaviruses and Apoptosis: Subversion of Cell Death. mBio 2017;8:e01009-17.

125 Moffatt S, Yaegashi N, Tada K, Tanaka N, Sugamura K: Human parvovirus B19 nonstructural (NS1) protein induces apoptosis in erythroid lineage cells. J Virol 1998;72:3018-3028.

126 Poole BD, Zhou J, Grote A, Schiffenbauer A, Naides SJ: Apoptosis of liver-derived cells induced by parvovirus B19 nonstructural protein. J Virol 2006;80:4114-4121.

127 Hsu TC, Wu WJ, Chen MC, Tsay GJ: Human parvovirus B19 non-structural protein (NS1) induces apoptosis through mitochondria cell death pathway in COS-7 cells. Scand J Infect Dis 2004;36:570-577.

128 Feng Q, Langereis MA, Lork M, Nguyen M, Hato SV, Lanke K, Emdad L, Bhoopathi P, Fisher PB, Lloyd RE, van Kuppeveld FJ: Enterovirus 2Apro targets MDA5 and MAVS in infected cells. J Virol 2014;88:3369-3378. 


\section{Cellular Physiology Cell Physiol Biochem 2021;55:679-703 \\ \begin{tabular}{ll|l} 
and Biochemistry & $\begin{array}{l}\text { DOl: 10.33594/000000470 } \\
\text { Published online: } 18 \text { November } 2021\end{array}$ & $\begin{array}{l}\text { C 2021 The Author(s). Published by } \\
\text { Cell Physiol Biochem Press GmbH\&Co. KG }\end{array}$ \\
\cline { 2 - 3 } &
\end{tabular}}

Ho et al.: CVB3 and PVB19 in Viral Myocarditis

129 Mukherjee A, Morosky SA, Delorme-Axford E, Dybdahl-Sissoko N, Oberste MS, Wang T, Coyne CB: The coxsackievirus B 3C protease cleaves MAVS and TRIF to attenuate host type I interferon and apoptotic signaling. PLoS Pathog 2011;7:e1001311.

130 Wang B, Xi X, Lei X, Zhang X, Cui S, Wang J, Jin Q Zhao Z: Enterovirus 71 protease 2Apro targets MAVS to inhibit anti-viral type I interferon responses. PLoS Pathog 2013;9:e1003231.

131 Esfandiarei M, Luo H, Yanagawa B, Suarez A, Dabiri D, Zhang J, McManus BM: Protein kinase B/Akt regulates coxsackievirus $\mathrm{B} 3$ replication through a mechanism which is not caspase dependent. J Virol 2004;78:4289-4298.

132 Autret A, Martin-Latil S, Brisac C, Mousson L, Colbère-Garapin F, Blondel B: Early phosphatidylinositol 3-kinase/Akt pathway activation limits poliovirus-induced JNK-mediated cell death. J Virol 2008;82:37963802.

133 Zhang H, Li F, Pan Z, Wu Z, Wang Y, Cui Y: Activation of PI3K/Akt pathway limits JNK-mediated apoptosis during EV71 infection. Virus Res 2014;192:74-84.

134 Mirabelli C, Pelletier I, Téoulé F, Vidalain PO, Brisac C, Tangy F, Delpeyroux F, Blondel B: The CREB3-Herp signalling module limits the cytosolic calcium concentration increase and apoptosis induced by poliovirus. J Gen Virol 2016;97:2194-2200.

135 Neznanov N, Kondratova A, Chumakov KM, Angres B, Zhumabayeva B, Agol VI, Gudkov AV: Poliovirus protein 3A inhibits tumor necrosis factor (TNF)-induced apoptosis by eliminating the TNF receptor from the cell surface. J Virol 2001;75:10409-10420.

136 Xin L, Xiao Z, Ma X, He F, Yao H, Liu Z: Coxsackievirus B3 induces crosstalk between autophagy and apoptosis to benefit its release after replicating in autophagosomes through a mechanism involving caspase cleavage of autophagy-related proteins. Infect Genet Evol 2014;26:95-102.

137 Li M, Wang X, Yu Y, Xie Y, Zou Y, Ge J, Peng T, Chen R: Coxsackievirus B3-induced calpain activation facilitates the progeny virus replication via a likely mechanism related with both autophagy enhancement and apoptosis inhibition in the early phase of infection: an in vitro study in H9c2 cells. Virus Res 2014;179:177186.

138 Song F, Yu X, Zhong T, Wang Z, Meng X, Li Z, Zhang S, Huo W, Liu X, Zhang Y, Zhang W, Yu J: Caspase-3 Inhibition Attenuates the Cytopathic Effects of EV71 Infection. Front Microbiol 2018;9:817.

139 Li ML, Hsu TA, Chen TC, Chang SC, Lee JC, Chen CC, Stollar V, Shih SR: The 3C protease activity of enterovirus 71 induces human neural cell apoptosis. Virology 2002;293:386-395.

140 Li J, Yao Y, Chen Y, Xu X, Lin Y, Yang Z, Qiao W, Tan J: Enterovirus 71 3C Promotes Apoptosis through Cleavage of PinX1, a Telomere Binding Protein. J Virol 2017;91:e02016-16

141 Li ML, Lin JY, Chen BS, Weng KF, Shih SR, Calderon JD, Tolbert BS, Brewer G: EV71 3C protease induces apoptosis by cleavage of hnRNP A1 to promote apaf-1 translation. PLoS One 2019;14:e0221048.

142 Chau DH, Yuan J, Zhang H, Cheung P, Lim T, Liu Z, Sall A, Yang D: Coxsackievirus B3 proteases 2A and 3C induce apoptotic cell death through mitochondrial injury and cleavage of eIF4GI but not DAP5/p97/NAT1. Apoptosis 2007;12:513-524.

143 Hanson PJ, Ye X, Qiu Y, Zhang HM, Hemida MG, Wang F, Lim T, Gu A, Cho B, Kim H, Fung G, Granville DJ, Yang D: Cleavage of DAP5 by coxsackievirus B3 2A protease facilitates viral replication and enhances apoptosis by altering translation of IRES-containing genes. Cell Death Differ 2016;23:828-840.

144 Melton JV, Ewart GD, Weir RC, Board PG, Lee E, Gage PW: Alphavirus 6K proteins form ion channels. J Biol Chem 2002;277:46923-46931.

145 Ewart GD, Sutherland T, Gage PW, Cox GB: The Vpu protein of human immunodeficiency virus type 1 forms cation-selective ion channels. J Virol 1996;70:7108-7115.

146 van Kuppeveld FJ, Hoenderop JG, Smeets RL, Willems PH, Dijkman HB, Galama JM, Melchers WJ: Coxsackievirus protein $2 \mathrm{~B}$ modifies endoplasmic reticulum membrane and plasma membrane permeability and facilitates virus release. EMBO J 1997;16:3519-3532.

147 Campanella M, de Jong AS, Lanke KW, Melchers WJ, Willems PH, Pinton P, Rizzuto R, van Kuppeveld FJ: The coxsackievirus 2B protein suppresses apoptotic host cell responses by manipulating intracellular Ca2+ homeostasis. J Biol Chem 2004;279:18440-18450.

148 Putney JW, Jr.: A model for receptor-regulated calcium entry. Cell Calcium 1986;7:1-12.

149 Putney JW, Jr: Store-operated calcium channels: how do we measure them, and why do we care? Sci STKE 2004;2004:pe37. 
Ho et al.: CVB3 and PVB19 in Viral Myocarditis

150 Zhou Y, Frey TK, Yang JJ: Viral calciomics: interplays between Ca2+ and virus. Cell Calcium 2009;46:1-17.

151 Williams GS, Boyman L, Chikando AC, Khairallah RJ, Lederer WJ: Mitochondrial calcium uptake. Proc Natl Acad Sci U S A 2013;110:10479-10486.

152 Tarasov AI, Griffiths EJ, Rutter GA: Regulation of ATP production by mitochondrial Ca(2+). Cell Calcium 2012;52:28-35.

153 Li Z, Zou Z, Jiang Z, Huang X, Liu Q: Biological Function and Application of Picornaviral 2B Protein: A New Target for Antiviral Drug Development. Viruses 2019;11:510.

154 Ow YP, Green DR, Hao Z, Mak TW: Cytochrome c: functions beyond respiration. Nat Rev Mol Cell Biol 2008;9:532-542.

155 Cai Z, Shen L, Ma H, Yang J, Yang D, Chen H, Wei J, Lu Q, Wang DW, Xiang M, Wang J: Involvement of Endoplasmic Reticulum Stress-Mediated C/EBP Homologous Protein Activation in Coxsackievirus B3Induced Acute Viral Myocarditis. Circ Heart Fail 2015;8:809-818.

156 Fung TS, Torres J, Liu DX: The Emerging Roles of Viroporins in ER Stress Response and Autophagy Induction during Virus Infection. Viruses 2015;7:2834-2857.

157 Han X, Cong H: Enterovirus 71 induces apoptosis by directly modulating the conformational activation of pro-apoptotic protein Bax. J Gen Virol 2017;98:422-434.

158 Wang H, Li Y: Recent Progress on Functional Genomics Research of Enterovirus 71. Virol Sin 2019;34:9-21.

159 Jiang D, Li M, Yu Y, Shi H, Chen R: microRNA-34a aggravates coxsackievirus B3-induced apoptosis of cardiomyocytes through the SIRT1-p53 pathway. J Med Virol 2019;91:1643-1651.

160 Du X, Wang H, Xu F, Huang Y, Liu Z, Liu T: Enterovirus 71 induces apoptosis of SH-SY5Y human neuroblastoma cells through stimulation of endogenous microRNA let-7b expression. Mol Med Rep 2015;12:953-959.

161 Chang YL, Ho BC, Sher S, Yu SL, Yang PC: miR-146a and miR-370 coordinate enterovirus 71-induced cell apoptosis through targeting SOS1 and GADD45 $\beta$. Cell Microbiol 2015;17:802-818.

162 Carthy CM, Granville DJ, Watson KA, Anderson DR, Wilson JE, Yang D, Hunt DW, McManus BM: Caspase activation and specific cleavage of substrates after coxsackievirus B3-induced cytopathic effect in HeLa cells. J Virol 1998;72:7669-7675.

163 Carthy CM, Yanagawa B, Luo H, Granville DJ, Yang D, Cheung P, Cheung C, Esfandiarei M, Rudin CM, Thompson CB, Hunt DW, McManus BM: Bcl-2 and Bcl-xL overexpression inhibits cytochrome celease, activation of multiple caspases, and virus release following coxsackievirus B3 infection. Virology 2003;313:147-157.

164 Paloheimo O, Ihalainen TO, Tauriainen S, Valilehto O, Kirjavainen S, Niskanen EA, Laakkonen JP, Hyoty H, Vihinen-Ranta M: Coxsackievirus B3-induced cellular protrusions: structural characteristics and functional competence. J Virol 2011;85:6714-6724.

165 Agol VI, Belov GA, Bienz K, Egger D, Kolesnikova MS, Romanova LI, Sladkova LV, Tolskaya EA: Competing death programs in poliovirus-infected cells: commitment switch in the middle of the infectious cycle. J Virol 2000;74:5534-5541.

166 Momoeda M, Wong S, Kawase M, Young NS, Kajigaya S: A putative nucleoside triphosphate-binding domain in the nonstructural protein of B19 parvovirus is required for cytotoxicity. J Virol 1994;68:8443-8446.

167 Sol N, Le Junter J, Vassias I, Freyssinier JM, Thomas A, Prigent AF, Rudkin BB, Fichelson S, Morinet F: Possible interactions between the NS-1 protein and tumor necrosis factor alpha pathways in erythroid cell apoptosis induced by human parvovirus B19. J Virol 1999;73:8762-8770.

168 Kytö V, Saraste A, Saukko P, Henn V, Pulkki K, Vuorinen T, Voipio-Pulkki LM: Apoptotic cardiomyocyte death in fatal myocarditis. Am J Cardiol 2004;94:746-750.

169 Clarke P, Tyler KL: Apoptosis in animal models of virus-induced disease. Nat Rev Microbiol 2009;7:144155.

170 Wang YF, Wang XY, Ren Z, Qian CW, Li YC, Kaio K, Wang QD, Zhang Y, Zheng LY, Jiang JH, Yang CR, Liu Q, Zhang YJ: Phyllaemblicin B inhibits Coxsackie virus B3 induced apoptosis and myocarditis. Antiviral Res 2009;84:150-158.

171 Wang Q, Zhu Q, Ye Q, Wang J, Dong Q Chen Y, Wang M, Fu Y, Wu R, Wu T: STAT3 Suppresses Cardiomyocytes Apoptosis in CVB3-Induced Myocarditis Via Survivin. Front Pharmacol 2020;11:613883.

172 Schulze K, Witzenbichler B, Christmann C, Schultheiss HP: Disturbance of myocardial energy metabolism in experimental virus myocarditis by antibodies against the adenine nucleotide translocator. Cardiovasc Res 1999;44:91-100. 


\section{Cellular Physiology Cell Physiol Biochem 2021;55:679-703 \\ \begin{tabular}{ll|l}
${ }$ and $10.33594 / 000000470 }$ & C 2021 The Author(s). Published by \\
Cell Physiol Biochem Press GmbH\&Co. KG
\end{tabular}}

Ho et al.: CVB3 and PVB19 in Viral Myocarditis

173 Xu J, Nie HG, Zhang XD, Tian Y, Yu B: Down-regulated energy metabolism genes associated with mitochondria oxidative phosphorylation and fatty acid metabolism in viral cardiomyopathy mouse heart. Mol Biol Rep 2011;38:4007-4013.

174 Sin J, McIntyre L, Stotland A, Feuer R, Gottlieb RA: Coxsackievirus B Escapes the Infected Cell in Ejected Mitophagosomes. J Virol 2017;91:e01347-17.

175 Lin L, Zhang M, Yan R, Shan H, Diao J, Wei J: Inhibition of Drp1 attenuates mitochondrial damage and myocardial injury in Coxsackievirus B3 induced myocarditis. Biochem Biophys Res Commun 2017;484:550-556.

176 Chen Q Vazquez EJ, Moghaddas S, Hoppel CL, Lesnefsky EJ: Production of reactive oxygen species by mitochondria: central role of complex III. J Biol Chem 2003;278:36027-36031.

177 Grivennikova VG, Vinogradov AD: Generation of superoxide by the mitochondrial Complex I. Biochim Biophys Acta 2006;1757:553-561.

178 Kannan K, Jain SK: Oxidative stress and apoptosis. Pathophysiology 2000;7:153-163.

179 Ebermann L, Wika S, Klumpe I, Hammer E, Klingel K, Lassner D, Volker U, Erben U, Zeichhardt H, Schultheiss HP, Dorner A: The mitochondrial respiratory chain has a critical role in the antiviral process in Coxsackievirus B3-induced myocarditis. Lab Invest 2012;92:125-134.

180 Xie B, Zhou JF, Lu Q, Li CJ, Chen P: Oxidative stress in patients with acute coxsackie virus myocarditis. Biomed Environ Sci 2002;15:48-57.

181 Peischard S, Ho HT, Piccini I, Strutz-Seebohm N, Röpke A, Liashkovich I, Gosain H, Rieger B, Klingel K, Eggers B, Marcus K, Linke WA, Müller FU, Ludwig S, Greber B, Busch K, Seebohm G: The first versatile human iPSC-based model of ectopic virus induction allows new insights in RNA-virus disease. Sci Rep 2020;10:16804.

182 Chi J, Yu S, Liu C, Zhao X, Zhong J, Liang Y, Ta N, Yin X, Zhao D: Nox4-dependent ROS production is involved in CVB. Biochem Biophys Res Commun 2018;503:1641-1644.

183 Eisner DA, Caldwell JL, Kistamás K, Trafford AW: Calcium and Excitation-Contraction Coupling in the Heart. Circ Res 2017;121:181-195.

184 Priest BT, McDermott JS: Cardiac ion channels. Channels (Austin) 2015;9:352-359.

185 Salerno F, Girerd N, Chalabreysse L, Billaud G, Lina B, Chevalier P: Myocarditis and cardiac channelopathies: a deadly association? Int J Cardiol 2011;147:468-470.

186 Steinke K, Sachse F, Ettischer N, Strutz-Seebohm N, Henrion U, Rohrbeck M, Klosowski R, Wolters D, Brunner S, Franz WM, Pott L, Munoz C, Kandolf R, Schulze-Bahr E, Lang F, Klingel K, Seebohm G: Coxsackievirus B3 modulates cardiac ion channels. FASEB J 2013;27:4108-4121.

187 Seebohm G, Strutz-Seebohm N, Ureche ON, Henrion U, Baltaev R, Mack AF, Korniychuk G, Steinke K, Tapken D, Pfeufer A, Kääb S, Bucci C, Attali B, Merot J, Tavare JM, Hoppe UC, Sanguinetti MC, Lang F: Long QT syndrome-associated mutations in KCNQ1 and KCNE1 subunits disrupt normal endosomal recycling of IKs channels. Circ Res 2008;103:1451-1457.

188 Ilnytska O, Santiana M, Hsu NY, Du WL, Chen YH, Viktorova EG, Belov G, Brinker A, Storch J, Moore C, Dixon JL, Altan-Bonnet N: Enteroviruses harness the cellular endocytic machinery to remodel the host cell cholesterol landscape for effective viral replication. Cell Host Microbe 2013;14:281-293.

189 Anacker C, Cattaneo A, Musaelyan K, Zunszain PA, Horowitz M, Molteni R, Luoni A, Calabrese F, Tansey K, Gennarelli M, Thuret S, Price J, Uher R, Riva MA, Pariante CM: Role for the kinase SGK1 in stress, depression, and glucocorticoid effects on hippocampal neurogenesis. Proc Natl Acad Sci U S A 2013;110:8708-8713.

190 Su YG, Yang YZ, Bao WS, Liu GX, Ge JB, Chen H: Effects of taurine and Astragalus membranaceus on ion currents and their expression in cardiomyocytes after CVB3 infection. Drug Development Research 2003;58:57-60.

191 Cheng J, Wen J, Wang N, Wang C, Xu Q, Yang Y: Ion Channels and Vascular Diseases. Arterioscler Thromb Vasc Biol 2019;39:e146-e156.

192 Dorsch S, Liebisch G, Kaufmann B, von Landenberg P, Hoffmann JH, Drobnik W, Modrow S: The VP1 unique region of parvovirus B19 and its constituent phospholipase A2-like activity. J Virol 2002;76:2014-2018.

193 Hernández-Araiza I, Morales-Lázaro SL, Canul-Sánchez JA, Islas LD, Rosenbaum T: Role of lysophosphatidic acid in ion channel function and disease. J Neurophysiol 2018;120:1198-1211.

194 Law SH, Chan ML, Marathe GK, Parveen F, Chen CH, Ke LY: An Updated Review of Lysophosphatidylcholine Metabolism in Human Diseases. Int J Mol Sci 2019;20:1149. 


\section{Cellular Physiology and Biochemistry}

Cell Physiol Biochem 2021;55:679-703

\begin{tabular}{l|l}
\hline DOI: 10.33594/000000470 & (c) 2021 The Author(s). Published by
\end{tabular}

Ho et al.: CVB3 and PVB19 in Viral Myocarditis

195 Lupescu A, Bock CT, Lang PA, Aberle S, Kaiser H, Kandolf R, Lang F: Phospholipase A2 activity-dependent stimulation of Ca2+ entry by human parvovirus B19 capsid protein VP1. J Virol 2006;80:11370-11380.

196 Behringer EJ: Calcium and electrical signaling in arterial endothelial tubes: New insights into cellular physiology and cardiovascular function. Microcirculation 2017; DOI: 10.1111/micc.12328.

197 Ahmed M, Honisch S, Pelzl L, Fezai M, Hosseinzadeh Z, Bock CT, Kandolf R, Lang F: Up-regulation of epithelial $\mathrm{Na}(+)$ channel ENaC by human parvovirus B19 capsid protein VP1. Biochem Biophys Res Commun 2015;468:179-184.

198 Ahmed M, Almilaji A, Munoz C, Elvira B, Shumilina E, Bock CT, Kandolf R, Lang F: Down-regulation of K ${ }^{+}$ channels by human parvovirus B19 capsid protein VP1. Biochem Biophys Res Commun 2014;450:13961401.

199 Ahmed M, Elvira B, Almilaji A, Bock CT, Kandolf R, Lang F: Down-regulation of inwardly rectifying Kir2.1 K+ channels by human parvovirus B19 capsid protein VP1. J Membr Biol 2015;248:223-229.

200 Zádori Z, Szelei J, Lacoste MC, Li Y, Gariépy S, Raymond P, Allaire M, Nabi IR, Tijssen P: A viral phospholipase A2 is required for parvovirus infectivity. Dev Cell 2001;1:291-302.

201 Ho HT, Peischard S, Strutz-Seebohm N, Klingel K, Seebohm G: Myocardial Damage by SARS-CoV-2: Emerging Mechanisms and Therapies. Viruses 2021;13:1880.

202 Kraft L, Sauter M, Seebohm G, Klingel K: In vitro Model Systems of Coxsackievirus B3-Induced Myocarditis: Comparison of Commonly Used Cell Lines and Characterization of CVB3-Infected iCell. Viruses 2021;13:1835. 